\title{
Dimensões Históricas da Internacionalização: o papel da diplomacia cultural alemã na mobilidade acadêmica transnacional (1919-1945)
}

André Felipe Cândido da Silva'

\section{Resumo}

A internacionalização é considerada um processo fundamental para aperfeiçoamento da qualidade do ensino superior e da pesquisa científica e como fruto da globalização contemporânea e das exigências por ela impostas. A mobilidade transnacional de estudantes e pesquisadores representa um dos principais aspectos da internacionalização, sendo perseguida e enfatizada pelas distintas políticas e atores que a promovem.

O presente artigo analisa a internacionalização como dinâmica histórica que nas primeiras décadas do século XX esteve associada às políticas de diplomacia cultural dos países europeus e Estados Unidos. Nesse sentido, pretende mostrar como ela se articulou com o intenso nacionalismo do período e com o esforço de modificar correlações de força pela conquista de nichos de identificação cultural. A análise se concentra na diplomacia cultural exercida pela Alemanha durante a República de Weimar e o regime nazista, país que esteve no epicentro dos dois conflitos mundiais, onde o incentivo ao intercâmbio de estudantes e acadêmicos assumiu sentidos específicos, referidos ao isolamento internacional pós-Tratado de Versalhes e à ambição de obter hegemonia cultural e política por meio de estratégias que variaram de acordo com o contexto político. Detalhará algumas ações direcionadas aos países latino-americanos, sobretudo ao Brasil.

Palavras-chave: Internacionalização. Mobilidade acadêmica. Diplomacia cultural. Política cultural externa alemã. República de Weimar. Alemanha nazista.

I Pesquisador da Casa de Oswaldo Cruz - Fundação Oswaldo Cruz - Centro de Documentação e História da Saúde. E-mail: andre-felipe.silva@fiocruz.br 
Nos últimos anos, as agências e instituições brasileiras de educação, ciência e tecnologia vêm enfatizando a importância da internacionalizaçáo como alavanca de desenvolvimento, qualificação e, ao mesmo tempo, de reconhecimento da pesquisa e ensino produzidos no País. As estratégias para alcançá-la não são acordes, como tampouco são acordes, ou claro o que se compreende como internacionalização (KNIGHT, 2004), talvez porque seja considerado como algo autoevidente, isto é, como o processo por meio do qual os agentes, meios e produtos do conhecimento tornam-se mais "internacionais". Em termos gerais, a internacionalização abrange a mobilidade de estudantes e pesquisadores, redes transnacionais de cooperação, por meio das quais se intercambiam conhecimentos e serviços, e a circulação e impacto da produção científica originada em um país.

A internacionalização acadêmica é reconhecida como expressão da globalização contemporânea e do primado do conhecimento na sua conformação. Nesse sentido, seria consequência lógica da maior possibilidade de conexão, franqueada pelas tecnologias digitais, e pela maior facilidade de circulação de pessoas e produtos. Vozes mais críticas têm chamado atenção para a desigualdade estrutural que marca a internacionalização acadêmica, já que formaçôes sociais com maior tradiçâo científica e universitária permaneceriam atuando como centros de atração de estudantes e pesquisadores, ao passo que aquelas de desenvolvimento acadêmico mais recente ou com sistemas de ensino e pesquisa menos consolidados e robustos continuariam como mananciais desses agentes. Fala-se em "internacionalização hegemônica”, expressão que marca esse desequilíbrio que favorece os países do Norte (SANTOS, 2002). A direção dos fluxos de acadêmicos e estudantes "[...] indica estruturas de dominação acadêmica e dependência cultural.” (CHARLE; SCHRIEWER; WAGER 2004, p. 13).

Esses desequilíbrios evidenciam os fatores econômicos, sociais, culturais e políticos ligados à internacionalização. Ela não é consequência intrínseca do desenvolvimento científico, nem da conectividade da sociedade global e do suposto primado do conhecimento. Tomada como um fim em si mesmo, ganha uma aura "ilusória e quase alquímica" (ARAÚJO; SILVA, 2015, p. 85-86), à medida em que autodesigna "[...] um conjunto de atributos susceptíveis de serem classificados como necessariamente vantajosos e imprescindíveis nos processos de construçáo identitária das universidades e centros de investigação". Segundo Antelo (2012), as questôes políticas 
e culturais devem ser levadas em conta na análise da internacionalização, que assume significados distintos segundo os campos disciplinares, as culturas científicas, as motivaçóes e as formaçóes sociais nas quais tem lugar. Ao identificá-la como expressão da globalização contemporânea ou como fruto espontâneo de fatores pertinentes à prática científica, perde-se não só a importância dessas questóes políticas e culturais, como também sua dimensão histórica. Hoje a internacionalização está institucionalizada em graus variados em programas de intercâmbio acadêmico, em políticas nacionais, nas estruturas de ensino e investigação. No entanto, essa institucionalidade é produto de um desenvolvimento histórico que ganhou vulto no século XX. Uma análise histórica possibilita conjugar os diferentes fatores, atores e interesses que confluíram em iniciativas e projetos de internacionalizaçáo, ainda que impelidos por motivaçóes náo necessariamente referidas a um ideal de internacionalidade ou cosmopolitismo, mas a ambiçôes de cariz nacionalista. Ela permite reconhecer o caráter multifacetado dos processos de internacionalização, que dessa forma se apresenta não como uma dinâmica geral e trans-histórica, mas como fruto de arranjos sócio-históricos específicos. A perspectiva histórica ajuda-nos a evitar encarar a internacionalização como consequência inexorável da evoluçáo das comunidades acadêmicas ou como processo lógico e necessário da gradativa universalização do conhecimento, a qual seria corolário do próprio estatuto epistemológico dos enunciados científicos. Como nos adverte Elisabeth Crawford (1992), a internacionalização não pressupóe um endosso do universalismo epistemológico, ou seja, a ideia de validade dos enunciados, independente do sujeito do conhecimento, do seu tempo e lugar. Interessa-nos como manifestação prática da crença e ação de sujeitos históricos; como dinâmica de circulação, por canais concretos, de formas específicas de conhecimento.

O objetivo deste artigo é contribuir para o debate histórico da internacionalização, de maneira a evidenciar como o campo da política externa, nomeadamente da diplomacia cultural, favoreceu açóes de parceria internacional e de mobilidade acadêmica através de fronteiras, em um consórcio de atores estatais e náo estatais mobilizados por interesses de diversas ordens. O foco recairá no caso alemáo, menos por ser representativo do que pela sua particularidade: protagonista dos dois principais conflitos bélicos do século XX, a Alemanha impulsionou suas açóes de promoção do 
intercâmbio acadêmico a partir da dolorosa experiência do primeiro deles e das condiçóes inauguradas pelo Tratado de Paz, em 1919. Sofreu particularmente os efeitos da crise do internacionalismo científico, originado exatamente em consequência do envolvimento das ciências e dos cientistas nos esforços de guerra e da sua defesa no terreno das ideias. Mesmo assim, a reputação internacional dos pesquisadores e universidades alemãs permaneceu atraindo acadêmicos de todo o mundo. A política externa da República de Weimar procurou capitalizar esse movimento em favor da reconstrução da imagem exterior da Alemanha, do restabelecimento dos intercâmbios comerciais e da retomada de vínculos políticos. A queda do frágil regime e a instauração da ditadura nazista trouxeram novos significados às açôes de mobilidade acadêmica. Apesar da repercussão negativa das políticas de perseguição política e racial e do suposto isolamento do país em razão da escalada das agressóes internas e externas do governo hitlerista, inclusive com certo anti-intelectualismo, desprezo pelas organizaçóes multilaterais e recusa da retórica internacionalista, houve continuidade na circulação de pesquisadores e estudantes alemães para o exterior e de estrangeiros para a Alemanha. Isso contraria ou pelo menos complexifica a ideia de que o nazismo e outras formas históricas de totalitarismo teriam sido fenômenos refratários ao internacionalismo.

O caso alemão ilustra o contexto em que o forte nacionalismo forjou as estratégias de parceria internacional, mesmo que as relaçóes bilaterais prevalecessem sobre esforços de inspiração internacionalista. Nesse sentido, ele não foi diferente de açóes semelhantes tomadas pelos franceses, e pelos ingleses e norte-americanos um pouco mais tarde. Naquele contexto, o internacionalismo científico articulou-se à dimensão nacional da atividade científica e ao exaltado nacionalismo de seus expoentes. "Em termos de prestígio intelectual e dominação, a internacionalização pode se manifestar como uma estratégia deliberada, imersa em contextos de intensa nacionalização e associada a eles.", advertem Christophe Charle, Jurgen Schriewer e Peter Wagner (2004, p. 12). Desse modo, nacionalismo e internacionalismo firmaram-se desde o século XIX como duas dimensóes constitutivas da prática científica, estabelecendo relações de tensão própria de atividades que envolvem cooperação e competição (FORMAN, 1973; CRAWFORD, 1992). 
A ambição de forjar contatos internacionais surgiu em grande medida da intenção de manter ou reconquistar prestígio nacional. Ao invés da homogeneização, interaçóes estabelecidas na arena internacional reafirmaram estilos nacionais de prática científica e acadêmica (HARWOOD, 1993). Como mostra Elizabeth Crawford (1992), mesmo no Prêmio Nobel, visto como ícone de uma ciência efetivamente internacional, as lealdades nacionais prevaleceram sobre o espírito internacionalista.

A ação estatal e lealdades nacionais interagiram na constituição de redes acadêmicas transnacionais, espontâneas, mas por vezes fomentadas por organizaçóes internacionais. Na maioria dos casos, os contatos transnacionais - no sentido de transferências que violam fronteiras, mas obedecem a parâmetros não necessariamente referidos aos Estados nacionais - assentaram-se na crença do internacionalismo científico.

É importante sublinhar que mesmo hoje em dia, em pleno vigor da chamada globalização e da "sociedade do conhecimento", em que se apregoa o enfraquecimento dos Estados-naçáo como atores das dinâmicas globais, a dimensão nacional permanece fulcral na internacionalização. Como afirma Crawford (1992), nos últimos cem anos a maior parte das atividades científicas é executada em instituiçóes nacionais, com financiamento frequentemente associado a propósitos nacionais e nacionalistas.

$\mathrm{Na}$ Alemanha do século XX, esse nacionalismo exacerbado adquiriu tonalidade e intensidade própria, expressando-se na ascensão de um regime totalitário fundado na ideia de superioridade racial, tradicionalismo cultural e expansionismo geográfico. Apesar das sabidas consequências dramáticas e inauditas desse regime, o nacionalismo intenso não foi exclusividade daquele país. Um olhar sobre a internacionalização nas primeiras décadas do século XX permite compreender que ela se constituiu de interaçóes e rivalidades, sendo acompanhada de ambiguidades marcantes naquele ambiente de nacionalismos acentuados.

O foco é sobre uma das principais estratégias de internacionalização: a mobilidade de estudantes e pesquisadores, bastante incentivada nos projetos e iniciativas apoiados pela diplomacia cultural germânica. É digno de nota o papel que as chancelarias e representaçóes diplomáticas tiveram na coordenação do intercâmbio acadêmico, em razão do significado político 
que ele assumiu nas primeiras décadas do século XX. Diplomatas e acadêmicos uniram-se nos esforços de propagar a cultura alemã no exterior, a partir do que se considerava uma de suas maiores realizaçóes - a ciência. Outros atores uniram-se a esse movimento, mobilizados pelo mesmo interesse ou por objetivos de outras ordens, dos quais não estiveram ausentes os interesses econômicos. Conforme afirma Stefan Rinke (1996), eles configuraram-se como atores transnacionais na medida em que se articularam em favor de objetivos comuns, mas cada qual resguardando seus próprios interesses.

A simbiose entre ciência e diplomacia foi possível graças ao crescente espaço da dimensão cultural nas relaçóes internacionais do século XX, propiciada pelo reforço da diplomacia cultural como estratégia de política externa. Como esclarece David-Fox (2006), a diplomacia cultural foi um fenômeno do século XX que se configurou a partir dos nacionalismos e imperialismos, assomando-se com a guerra total.

O lugar que as ciências e as universidades ocuparam na diplomacia cultural deve-se à dimensão das ciências na esfera da cultura e imaginário social de uma forma geral e ao significado que assumiram como expressão de grandeza nacional. As universidades tornaram-se repositórios da cultura nacional e os eruditos seus mais eminentes representantes. Eles colaboraram com a criação do que se convencionou reconhecer como "alta cultura", importante para consolidar a unidade simbólica da nação. Ajudaram ainda a construir as tradiçóes das grandes universidades nacionais, tornando-as instrumentos de prestígio e alavancas da modernização nacional (CRAWFORD, 1992, p. 32). Desse ponto de vista, podemos compreendê-los como "Kulturträger": como "portadores" ou "emissários" da cultura nacional, que a divulgam entre seus pares no estrangeiro a partir do domínio de um saber. Não são mensageiros neutros ou meras peças de um estratagema coeso, formulado nos gabinetes dos órgãos de Estado. Conforme veremos, foram partícipes ativos na execução dessa política cultural externa, mobilizados por convicção íntima, pois foram, eles próprios, nacionalistas, mais ou menos aguerridos. Perseguiram, sobretudo, seus objetivos de natureza acadêmica: estabelecer relaçôes com os pares no exterior, viabilizar agendas de pesquisa, formular programas comuns de investigação, por vezes inviabilizados em seu país; recrutar estudantes para 
seus cursos e laboratórios, ampliar audiências, tudo isso conjugado com a finalidade de avultar seu capital simbólico, dessa forma avantajando o potencial de disputa no litigioso campo científico (BOURDIEU, 2004). Por conta desse protagonismo, não atuaram como epifenômenos das relaçóes internacionais. Certamente que as injunçôes da política internacional influenciaram a circulação desses personagens, mas eles foram coconstrutores dessa ordem, mais do que meros atores perfilando em um cenário estático.

$\mathrm{Na}$ construção de um "império informal” alemão, baseado no intercâmbio comercial e cultural, ao lado de outros atores, "[...] professores e estudantes tornaram-se mensageiros das ideias alemãs.”, sustenta Stephen Gross (2016, p. 2). Gross, como Ninhos (2016), argumenta que a esfera cultural pode ser compreendida como o "soft power" das relações internacionais, tal como definido por Joseph Nye, como "[...] a capacidade de obter o que deseja através da atração, em vez de coerção ou do suborno. Ele surge a partir da atratividade pela cultura de um país, pelos ideais políticos e pela política." Nye (apud NINHOS, 2016, p. 9). No entanto, em trabalho sobre o intercâmbio médico-científico entre Alemanha e Rússia no entreguerras, Susan Solomon (2006, p. 8) defende que, enquanto o "soft power" é manejado por uma nação forte para difundir sua cultura e conquistar simpatias em favor de seus posicionamentos, "[...] os alemães viram o Machtersatz [a ideia da ciência como substituta para o poder militar e econômico comprometidos com a Guerra; motriz da diplomacia cultural executada na República de Weimar, como veremos adiante] como um estratagema apropriado unicamente para uma nação que era incapaz de flexionar seus músculos”. Solomon também argumenta que a noção alemã da ciência como substituta do poder pressupóe que a ciência é forte, ou seja, representa "[...] uma inequívoca demonstração da superioridade intelectual da nação.” (SOLOMON, 1996, p. 8). Menos do que aprofundar as compreensóes da dimensão cultural das relaçóes internacionais e da diplomacia e propaganda cultural, importa-nos aqui evidenciar como foram instâncias fundamentais para a mobilidade acadêmica transnacional de estudantes e pesquisadores na primeira metade do século XX.

O presente trabalho baseia-se em análise da literatura especializada sobre o tema e em documentação do Ministério das Relaçóes Exteriores alemão e do Arquivo Secreto do Estado Prussiano. Primeiramente trato da 
dimensão histórica da mobilidade acadêmica nas universidades e centros de investigação e de sua instrumentalização com propósitos de diplomacia cultural, na qual a França foi pioneira. Em seguida, abordo as circunstâncias pós-Tratado de Versalhes, quando ganhou força na Alemanha uma política cultural externa com forte acento no intercâmbio acadêmico. Por fim, analiso como o Terceiro Reich procurou dar continuidade a essa política em um cenário marcado por disputas entre órgáos, pelos efeitos da expulsão dos acadêmicos judeus e pela sobreposição crescente entre a política cultural e a propaganda, esferas que se procurou distinguir durante a República de Weimar. Detalho ao longo da narrativa algumas açóes de política cultural externa direcionadas para a América Latina, especificamente para o Brasil.

\section{Universidades, intercâmbio acadêmico e diplomacia cultural}

Se desde o período medieval observa-se a mobilidade acadêmica entre as universidades, essa migração assumiu novos sentidos com a gradual nacionalização das instituiçôes de ensino. De 1850 em diante, os sistemas educacionais tornaram-se cada vez mais vistos como específicos e característicos de uma nação peculiar em termos de idioma, mas também de titulação e perfil de currículo. Particularmente os sistemas franceses e alemães emergiram como distintos e concorrentes (WERNER, 2004). Até a Segunda Guerra, os dois iriam concentrar a maior parte da demanda do mercado acadêmico das universidades ocidentais (KARADY, 2004, p. 371).

Em solo germânico, desenvolveu-se a concepção de universidade moderna a partir dos ideais de Wilhelm von Humboldt, que os aplicou na Universidade de Berlim em 1810, inspirado pelas concepçóes do iluminismo alemão. Baseava-se no ideal de busca livre e autônoma do conhecimento e na autogestão da corporação universitária. A universidade tornava-se não apenas um espaço de ensino, mas também de pesquisa, organizada em uma estrutura hierárquica encimada pelos professores catedráticos, secundados por seus assistentes e com ampla autonomia na configuração e gerência dos institutos e áreas de conhecimento. Dessa forma, assentaram-se as bases institucionais para o desenvolvimento da pesquisa científica como 
atividade profissional. Com a unificação Alemã e a vitória na Guerra Franco-Prussiana, as universidades germânicas participaram de forma ativa na construção nacional, por atuarem como as guardiãs da alta cultura e como espaços que ajudaram na coesão nacional devido a seu papel na educação superior, que a partir daí alcançou enorme crescimento. O conhecimento baseado nas aplicaçôes científicas foi decisivo para o salto de crescimento industrial do país, que ganhou dinamismo depois da unificação. ${ }^{2}$

As exigências práticas do acelerado desenvolvimento industrial alemão ocasionaram a diversificaçáo do sistema acadêmico, com a criação de escolas técnicas de ensino superior. $\mathrm{O}$ modelo alemão de ensino e pesquisa inspirou reformas universitárias em vários países do mundo. Apesar da autonomia e liberdade intelectual que vigorava nas universidades alemãs, o Estado germânico recém-constituído como entidade unificada, aportou enorme quantidade de recursos no ensino e pesquisa acadêmicos. Os professores universitários eram contratados como servidores públicos de alta remuneração e prestígio. Seguindo o padrão germânico, países europeus, como também países de fora da Europa, a exemplo do Japão e EUA, modernizaram seus sistemas acadêmicos, baseando-se nas universidades como centros de pesquisa. Muitos buscaram assegurar o controle sobre essas instituições pela alocação de recursos, nomeação de professores, políticas de acesso de estudantes e conformação de currículos. O grau de liberdade acadêmica variou de acordo com as configuraçôes específicas, nas quais o nível de controle do Estado atuou como parâmetro importante (KARADY, 2004, p. 364).

$\mathrm{Na}$ França, a derrota na Guerra Franco-Prussiana foi percebida como consequência de um sistema acadêmico defasado em comparação com o alto nível de desenvolvimento da ciência alemã. O nacionalismo extremado durante e depois desse conflito acirrou a disputa entre alemães e franceses por hegemonia cultural, disputa na qual as universidades e centros de pesquisa se tornaram um importante flanco. As realizaçóes científicas e o prestígio acadêmico cada vez mais foram instrumentalizados como emblemas de grandeza nacional. Ao mesmo tempo, a circulação internacional

2 Sobre esse processo ver Szöllözi-Janze (2005). 
de pessoas, mercadorias e ideias ganhava densidade, ventilada por ideais de internacionalismo e cosmopolitismo, nos quais a ciência figurava como componente de peso. A já mencionada tensão entre esses dois impulsos da prática científica e acadêmica foi marcante e característica do período que vai do último quartel do século XIX até o final da Segunda Guerra, passando por reconfiguraçôes importantes na Primeira e no período entre os dois conflitos. Em termos práticos, o internacionalismo manifestou-se em cooperaçóes nos campos da astronomia, meteorologia, geologia etc.; na criação de associaçóes disciplinares internacionais, nos cada vez mais frequentes congressos científicos, nos esforços de padronização da linguagem, métricas e instrumentos, na circulação de publicaçóes e articulação de bibliografias internacionais. Como no caso do Catálogo Internacional da Literatura Científica, explorado por Fuchs (2004), a orientação internacionalista de cooperar com os pares e avançar as fronteiras científicas foi inseparável da finalidade de "difundir a superioridade nacional" (FUCHS, 2004, p. 190).

A mobilidade de estudantes e professores foi outra manifestação importante desse éthos internacionalista e universalista, marcante na chamada Belle Époque. Eles dirigiram-se para as tradicionais universidades europeias em busca de conhecimento especializado, capital simbólico e intelectual, habilidades linguísticas e das vantagens de estudar nas metrópoles cosmopolitas que sediavam os grandes centros acadêmicos, como Paris, Berlim e Viena (KARADY, 2004, p. 374).

Até a Primeira Guerra, a rede de instituiçóes alemãs de ensino superior figurou como liderança internacional, atraindo para seus bancos estudantes e professores estrangeiros que para elas afluíam em grande número, interessados em alavancar suas carreiras e reputaçôes pela formação em centros de prestígio, ou em aplicar, em seus locais de origem, as inovaçóes que asseguravam a excelência das universidades do Reich. A Alemanha tornou-se "[...] o centro da gravidade da mobilidade internacional." (NINHOS, 2016, p. 33). A massiva migração de estudantes para as universidades alemâs foi o primeiro caso nesse movimento de um padrão de mobilidade "[...] completamente induzido por motivos relativos às qualidades inerentes de um sistema de educaçáo superior e pela ciência." (SCHRIEWER, 2004, p. 336). Até 1890, três quartos da demanda acadêmica internacional 
orientaram-se para instituiçóes alemãs (KARADY, 2004, p. 371). Em 1904, 8.786 estudantes estrangeiros deles encontravam-se na Alemanha, ao passo que na França havia 2.046 estudantes estrangeiros e, nos Estados Unidos, 2.643 (PRESAS I PUIG, 2008, p. 531). A liderança alemã também pode ser verificada pela alta prevalência de publicaçóes científicas que vinham da Alemanha e/ou eram veiculadas em alemáo.

Apesar do enorme prestígio e força de atração de suas universidades, o Império Alemão perseguiu as ambiçóes de hegemonia internacional usando as ferramentas tradicionais de coerção pelo poder militar e naval e força econômica. Nos anos 1890, quando a Alemanha já ocupava posição de relevo no cenário internacional e seu modelo de desenvolvimento súbito despertava admiração, um grupo de jovens intelectuais passou a defender estratégias de influência alternativas à Weltpolitik privilegiada pelo império Guilhermino. Os alemães deveriam se apoiar na força de sua cultura, sobretudo no prestígio de suas universidades e das ciências, para espalhar suas ideias, conquistar mercados e nichos de influência no estrangeiro (KLOOSTERHUIS, 1994; MICHELS, 2004). Em carta ao historiador Karl Lamprecht de 1912, o chanceler Benthmann Hollweg utilizou a expressão política cultural externa (auswärtige Kulturpolitik) para enfatizar a necessidade de a Alemanha conquistar prestígio mundial por meio de uma política cultural sistemática (DUWELL, 1976; GOEBEL, 2009, p. 230). A proposta trouxe poucas consequências práticas, apesar de já existirem algumas iniciativas oficiais que apontavam naquele sentido.

Em 1905, o Ministério da Educação da Prússia firmara acordos de intercâmbio com as universidades de Columbia e Harvard, os quais vigoraram até o início da Primeira Guerra (Von BROCKE, 1981). A circulação de ideias e pessoas entre a Alemanha e os Estados Unidos, avultado desde a segunda metade do século XIX, teria enormes consequências para ambos os países. O modelo alemão foi de suma importância para o estabelecimento das universidades norte-americanas, que depois da Segunda Guerra iriam influenciar a reforma das congêneres alemãs (FUSSL, 2004). Os americanos que estudaram na Alemanha "[...] tornaram-se apóstolos da ideia alemã, e por todo o país eles propagaram o evangelho da pesquisa especializada, do conhecimento de primeira mão e da liberdade de aprendizado e ensino." (DREWEK, 2004, p. 255). Praticamente todo o grupo 
de pessoas envolvidas na criação das primeiras universidades americanas após 1870 estudou na Alemanha pelo menos na primeira fase de sua vida acadêmica (STICHWEH, 2004, p. 354).

O intercâmbio entre os dois países chamou atenção dos franceses. O professor de filosofia da Sorbonne, Emile Boutroux, propôs maior apoio oficial para que a França também perseguisse uma política orgânica de relaçôes acadêmicas com o exterior, as quais deveriam ir além das palestras de norte-americanos dirigidas para audiências de falantes do inglês (CHARLE, 2004, p. 404). Em 1909, esse intercâmbio foi institucionalizado, envolvendo a Universidade de Sorbonne com as universidades de Harvard e Columbia. Uma cadeira financiada pelas universidades dos dois países foi estabelecida em Columbia. Um ano antes, um conjunto de acadêmicos franceses havia criado o Groupement des Universités et des grandes Écoles de France pour les Rapports avec l'Amerique Latine, órgão destinado a coordenar as relaçóes culturais com a América Latina por meio do intercâmbio acadêmico. Intensa circulação de professores entre a França e países latino-americanos teve lugar a partir daí. Brasil e Argentina foram os principais endereços das visitas de acadêmicos franceses. $\mathrm{O}$ principal articulador desse movimento rumo à América Latina foi o médico e psicólogo francês George Dumas que levou à frente a criação, nos anos 1920, de uma rede de institutos bilaterais da França com o Brasil, Argentina, Chile, Venezuela, Peru, México e Colômbia. ${ }^{3}$

Na virada do século XIX para o XX, as ciências haviam se integrado mais à política externa das naçóes. No contexto da corrida imperialista, as metrópoles que disputavam a hegemonia mundial haviam passado a usar as ciências, suas aplicaçóes e outros bens culturais, como nunca se tinha feito antes, nas estratégias de política externa destinadas a fomentar relaçóes econômicas, modificar correlaçóes de força em termos de domínio, influência ou prestígio, ou para angariar o apoio de aliados num possível enfrentamento por possessóes coloniais. A América Latina foi um dos teatros das lutas por influência entre as potências europeias e a nova força imperialista, os Estados Unidos, sendo alvo da ação de organismos criados

3 Sobre as ações da diplomacia cultural e o papel de George Dumas nele, ver: Petijean (1996), Suppo (2000) e Sá e Viana (20/0). 
nas metrópoles para promover as relaçóes intelectuais e difundir a cultura do país de origem (PETITJEAN, 1996, p. 31).

A França havia iniciado sua diplomacia cultural a partir da difusão do idioma, partindo do pressuposto de que "[...] todo cliente da língua francesa é um cliente natural dos produtos franceses." (apud SUPPO, 2010, p. 312). Em 1883, criou-se a Aliança Francesa, que se expandiu com apoio da diplomacia, do Ministério das Colônias e do Ministério do Interior. Desde 1860, o Ministério das Relaçóes Exteriores francês deu suporte à criação de estabelecimentos judaicos e evangélicos para ensino da língua francesa no estrangeiro, sendo que até 1900 mais de 50 mil missionários católicos haviam sido enviados ao exterior (SANTOMAURO, 2012, p. 212).

A política cultural que se desenvolveu a partir daí ganhou expressão com a criação, em 1910, do Bureau des écoles et des oeuvres françaises à l'étranger, órgáo que passou a coordenar, sob as mãos da diplomacia, as relaçóes até então protagonizadas por órgãos privados, como a Aliança Francesa. O Ministério das Relaçóes Exteriores teve enorme aumento de orçamento com a finalidade de levar adiante as iniciativas de uma política cultural sistemática. Os professores universitários, ao lado de artistas, escritores e jornalistas, foram partícipes cruciais desse esforço, em razâo da relevância que o intercâmbio acadêmico assumiu para os propósitos de “irradiação cultural” (rayonnement) (SUPPO, 2000, p. 312). Os dínamos dessa política cultural foram esses “[...] homens conhecedores de todos os problemas universitários, em contato com as grandes personalidades do mundo intelectual, tendo ao mesmo tempo o conhecimento e a experiência do estrangeiro, e dos meios científicos e pedagógicos." (SUPPO, 2000, p. 316).

Utilizando canais próprios, professores universitários multiplicavam as conexóes com sociedades e colegas estrangeiros, mobilizados pela crença no internacionalismo científico e, ao mesmo tempo, convictos do papel das ciências como emblemas de poder e hegemonia cultural da naçáo. Os convites a professores e personalidades ilustres para palestrarem em universidades e instituiçóes culturais estrangeiros representaram uma das principais estratégias de promoção de relaçóes acadêmicas transnacionais. A Sorbonne teve destaque nessa política de convites. Conforme mostra 
Christophe Charle (2004b, p. 413), os acadêmicos franceses privilegiaram nessa investida de política cultural os países que já se encontravam na órbita de influência cultural da França, mais do que aqueles que demandavam competição efetiva. Esses foram favorecidos por uma audiência já cativa, que identificava na França o berço da alta cultura, do beletrismo, das artes e das instituiçóes políticas modernas, sendo suas universidades e instituiçóes acadêmicas vistas como inspiradoras das similares estabelecidas no exterior. Charle (2004b) ainda distingue dois perfis desses acadêmicos: os "embaixadores" e os "especialistas", sendo os primeiros predominantemente ligados às humanidades; endereçavam-se em suas missóes no exterior a audiências mais amplas com temas de interesse geral, apresentados a partir de uma perspectiva francesa e que promovia a imagem da França e a excelência de sua cultura. Já os especialistas detinham-se sobre temas de suas áreas de competência, não deixando de apontar deficiências do sistema acadêmico francês ou aspectos dele que julgavam modelares e dignos de serem imitados.

Em consequência do prestígio das universidades da Europa ocidental e da centralidade que elas gradativamente assumiram na diplomacia cultural, em 1910 cerca de $15 \%$ das vagas eram ocupadas por estudantes internacionais (KARADY, 2004, p. 370). Inspiradas pelo modelo alemão, as instituiçóes norte-americanas aos poucos se fortaleceram, passando a competir com os europeus no mercado acadêmico internacional e na disputa por prestígio científico. Não passou despercebido dos alemães a preeminência que a ciência norte-americana foi assumindo à medida em que adentrava o século XX. Para ombrear-se com os EUA, o império alemáo criou em 1911 a Sociedade Kaiser Wilhelm, responsável por uma série de institutos de pesquisa dedicados a abrir novos horizontes em várias áreas de conhecimento das ciências naturais. Os institutos nasciam sob a paternidade do Estado imperial, patrocinados por uma fundação com representação de cientistas, industriais e burocratas do governo. Os Institutos Kaiser Wilhelm, depois da Segunda Guerra, rebatizados de Instituto Max Planck, atraíram pesquisadores e estudantes de todo o mundo, firmando-se como posto importante de intercâmbio acadêmico fora das universidades e escolas superiores.

A Primeira Guerra representou uma ruptura nesse desenvolvimento e na migração acadêmica transnacional. $\mathrm{O}$ número de estudantes internacionais nas instituições do Velho Mundo caiu abruptamente. Professores 
como estudantes europeus participaram direta e indiretamente da mobilização, indo atuar no teatro de guerra ou compondo a rede que aproximou cientistas, indústria e Estado no desenvolvimento e fabricação de artefatos bélicos. Se por um lado isso impulsionou a constituição do complexo acadêmico-militar-industrial que caracterizaria a Big Science no século XX, bem como a formação de sistemas nacionais mais azeitados de coordenação da atividade científica, por outro evidenciou o profundo comprometimento dos cientistas com suas respectivas comunidades nacionais. Isso feriu o ideal do internacionalismo científico, que havia impulsionado as iniciativas de mobilidade acadêmica até então. As comunidades de origem dos "clientes" que rumavam para as universidades europeias segmentaramse entre "germanófilos" e "aliadófilos". Por simpatia e identificação cultural muitos deles associaram-se ao lado dos países onde tinham se formado ou completado sua formação. Particularmente traumático foi o chamado Manifesto dos 93, assinado por grandes expoentes da ciência alemã, inclusive muitos dos ganhadores do Prêmio Nobel. Nele contestaram afirmaçóes divulgadas pelos Aliados, como a de que a Alemanha havia sido a causadora da Guerra, de que ela havia criminosamente ferido a neutralidade belga; repudiaram as supostas barbaridades que as tropas alemãs teriam cometido na Bélgica e defenderam a identidade entre a cultura e o militarismo germânicos. Dessa forma, revogava-se a ideia sustentada pelos Aliados da existência de duas Alemanhas: uma militarista, radical e autoritária e outra intelectual, liberal, das letras, do saber, das ciências. Essas duas dimensóes tornaram-se de tal modo imbricadas que muitos assinaram o manifesto antes mesmo de conhecer seu conteúdo; achavam-se atacados em seus brios nacionalistas pelo que viam como uma campanha de difamação pelos adversários. ${ }^{4}$

As consequências desse envolvimento profundo dos cientistas e intelectuais em defesa da Guerra e do ideário nacionalista se arrastariam pelos anos seguintes. Para os franceses, a vitória de 1918 representou uma oportunidade de intensificar as iniciativas de diplomacia cultural pela promoçáo dos vínculos acadêmicos e de deslocar em seu favor o eixo de influência científica. Nisso seriam beneficiados pelo isolamento da ciência

4 Sobre o Manifesto dos 93, ver: Unger-Sternberg E Unger-Sternberg (2014) 
alemã e pela profunda crise econômica, social e política que assolava o país. Os alemães, por sua vez, receberam o Tratado de Paz como um Diktat. Conscientes da importância que as engrenagens da propaganda tiveram no desenrolar do conflito e da força e prestígio de sua ciência e instituiçóes, ao mesmo tempo em que restritos nas possibilidades de reconquistar posiçáo no cenário internacional, impulsionaram de forma mais sistemática uma política cultural na qual a circulação de estudantes e pesquisadores teria um importante papel. A diplomacia cultural francesa foi a inspiraçáo e ao mesmo tempo a principal oponente nesse esforço.

\section{Ciências e universidades como emblemas de poder: a diplomacia cultural alemã e a circulação acadêmica na República de Weimar}

As cláusulas do Tratado de Versalhes limitaram de forma significativa as abordagens de política externa tradicionalmente perseguidas pela Alemanha, já que o país se encontrava em meio a severa crise financeira e com seu exército e marinha bastante reduzidos. Dessa forma ganhou vulto a ideia de pôr em ação uma política cultural externa - auswärtige Kulturpolitik - capaz de recuperar o prestígio internacional da Alemanha, abrir caminho para o comércio e indústria, conquistar influência entre círculos políticos estrangeiros, tudo isso sem despertar suspeitas entre as potências vencedoras, que acompanhavam de perto as movimentaçóes dos alemães no exterior (DUWELL, 1981; WULF, 1994; RINKE, 1996; GOEBEL, 2009). Em março de 1918, um grupo de comerciantes de Hamburgo sugeriu uma reforma do Ministério das Relaçóes Exteriores capaz de incorporar a dimensão da política cultural (WULF, 1994; URBAN, 2005). No ano seguinte, o Ministro da Educação da Prússia, Carl Heinrich Becker, apresentou ao congresso alemão memorando no qual apontava a importância de uma política cultural alemá, sustentando que, para tal, era fundamental que se aumentasse o apoio financeiro à ciência.

Os acadêmicos alemães fizeram coro à proposta, amparando-se na ideia de que restava apenas a ciência como expressão do poder internacional da Alemanha, já que a mesma se encontrava despida de poder político e militar. Eles defendiam uma política cultural externa para reconstruir 
os laços com os pares estrangeiros, comprometidos com a Guerra, mas principalmente para contornar o boicote internacional imposto pelos países aliados. Os alemães foram proibidos de participar de duas associaçóes internacionais criadas em 1919 por consórcios de academias aliadas: o Conselho Internacional de Pesquisas (International Research Council) e a União Acadêmica Internacional (Union Académique International). Seus nomes foram retirados das sociedades científicas internacionais, o alemão foi proibido de ser empregado como idioma nos certames científicos e publicaçôes, e a circulação de seus periódicos foi restringida. Mesmo os gestos conciliatórios de pesquisadores suecos, holandeses e norte-americanos foram insuficientes para neutralizar a postura beligerante das academias aliadas (KIRCHHOFF, 2003, p. 59). Como diz Brigitte Schroeder-Gudehus (1978), o armistício intelectual se mostraria mais lento e laborioso que o militar. Silenciada a batalha das trincheiras, ela teve continuidade entre os cientistas, ressentidos do apoio que os pares haviam dado à mobilização militar e do ataque impetrado aos oponentes.

Paul Forman (1973) analisa minuciosamente esse contexto, concentrando-se na comunidade de físicos alemães. Ele mostra como ganhou espaço, entre os professores universitários e pesquisadores, a ideia da ciência como "compensadora" do poder político militar perdidos - Machtersatz. Irritados com as cláusulas de Versalhes, descontentes com a República de Weimar, à qual não reconheciam como legítima, eles se colocaram como os autênticos representantes da nação alemã, de maneira que a ciência figurou como instrumento de poder político, único que restava, a despeito de todas as dificuldades, em termos de reputação internacional. Nesse sentido, juraram fidelidade não ao governo, mas à nação, defendendo, ao mesmo tempo, o internacionalismo científico, que julgavam estar comprometido pelas atitudes restritivas dos colegas Aliados (FORMAN, 1973).

Se antes da Guerra o estatuto de potência científica assentava-se na hegemonia política assegurada pelo poderio econômico e militar, agora as ciências deveriam ser o sucedâneo desse poderio, em um país prostrado pela crise econômica, pela derrota militar, às voltas com levantes revolucionários e governado por um regime democrático que despertava ódio à direita e à esquerda do espectro político (FORMAN, 1973). 
As ambiçôes dos políticos e cientistas concretizaram-se em 1920, quando foi criada uma Divisão Cultural no Ministério das Relações Exteriores dedicada às escolas alemãs no exterior, às colônias de alemáes fora da Alemanha e ao intercâmbio de cientistas e estudantes. Dessa forma, ganhou expressão institucional a ideia de que as relaçóes culturais, que incluíam as ciências e as artes, passariam a compor as abordagens da política exterior germânica (SOLOMON, 2006, p. 8).

É importante mencionar que a visita de pesquisadores alemães ao exterior, de recepção de acadêmicos estrangeiros e de intercâmbio de estudantes, publicaçóes e concessão de honrarias, as principais ferramentas dessa política cultural externa, baseou-se nos contatos e redes informais que uniam os cientistas. Só foi possível aos cientistas alemães resistir ao boicote e negociar politicamente a reintegração ao cenário internacional devido a essas relaçóes pessoais, que em grande medida se mantiveram ou se restabeleceram uma vez terminada a Guerra (FORMAN, 1973; PRESAS I PUIG, 2008).

Para a diplomacia alemã, o engajamento de acadêmicos e personalidades na política cultural externa ofereceu a vantagem de difundirem a cultura alemã sem atuarem como seus representantes oficiais. Os oficiais empregaram a expressão "propaganda" e "política" cultural como termos mais ou menos intercambiáveis, embora houve esforços no sentido de tentar distinguir as duas abordagens, sendo a primeira vista como veículo mais evidente de convencimento político, caráter mais massivo e de curto prazo, ao passo que a política cultural teria em mira o cultivo de laços com as elites culturais e políticas, com estratégias visando o médio e longo prazo (DUWELL, 1976). Apenas aos poucos elas foram se separando nas repartiçóes e estratégias do Ministério (RINKE, 1996, p. 121).

Os grupos envolvidos no comércio exterior participaram intensamente dessa política cultural, conscientes de que o consumo de bens culturais franqueava espaço para o de produtos manufaturados e serviços. Em Hamburgo, importante porto de chegada e saída de mercadorias e pessoas, companhias comerciais e de navegação envolveram-se na criação de órgãos cuja finalidade era estreitar os laços culturais com países estrangeiros por meio de estratégias que incluíam o intercâmbio de estudantes, professores e 
personalidades. Instituiçóes hanseáticas de pesquisa e estudo, como o Instituto de Doenças Marítimas e Tropicais de Hamburgo (Institut fur Schiffs- und Tropenkrankheiten), colaboraram nesse esforço (WULF, 1994). A elas somou-se a Universidade de Hamburgo, fundada em 1919. A América Latina representou um importante alvo das investidas de política cultural oriundas da cidade portuária, em virtude das históricas conexôes que havia com a região por conta do comércio e dos fluxos migratórios (URBAN, 2005). Náo por acaso, a Universidade de Hamburgo recebeu número significativo de estudantes latino-americanos. $\mathrm{O}$ Instituto Ibero-Americano de Hamburgo, criado em 1917, atuou como posto de aconselhamento e encaminhamento de uma série de estudantes que rumaram para a cidade. Seu diretor, Bernhard Schädel e também responsável pelo Seminário de Romanística e do Centro Ibero-Americano, procurou facilitar a ida de estudantes dos países ibéricos e latino-americanos. O Instituto Ibero-Americano também coordenou viagens de acadêmicos pela Espanha, Portugal e América Latina, encarregados de promover o intercâmbio de estudantes dos países visitados com a Alemanha. Schädel foi um dos idealizadores da criação, na Espanha, das Juntas Españolas para el Intercambio Cientifico con Alemania, a partir das quais se desenvolveram centros de estudos alemães em Madrid e Barcelona. Agências alemãs estabeleceram relaçóes com a Junta para Ampliación de Estudios, que concedeu bolsas para espanhóis estudarem no exterior, dos quais um quarto dos contemplados entre 1910 e 1934 foi para instituiçóes germânicas (RINKE, 1996; SÁNCHEZ, 2003; PRESAS I PUIG, 2008; JANUÉ I MIRET, 2015). Schädel criticou os obstáculos para esses estudantes afluírem em grande número para a Alemanha, como as vultosas taxas de matrícula e a limitação linguística, que várias associaçóes procuraram superar pela oferta de cursos gratuitos de alemão. Schädel lembrou que os franceses ofereciam essas facilidades para os estrangeiros que rumavam para suas universidades (RINKE, 1996).

Por causa do sucesso das viagens dos médicos Peter Muhlens e Max Nonne à América Latina, os representantes de Hamburgo solicitaram ao Ministério das Relaçóes Exteriores subvenção anual de 10 mil marcos para a Universidade de Hamburgo. Com esse recurso, esperavam criar um posto permanente de coordenação do intercâmbio de estudantes e professores 
com a Universidade de Buenos Aires, mas o projeto esbarrou na oposição do legado alemão na Argentina. ${ }^{5}$ A Câmara de Comércio de Hamburgo a partir de 1924 passou a conceder bolsas para estudantes da América Latina e dos países ibéricos (URBAN, 2005).

Professores alemães que percorreram o estrangeiro apontaram em seus relatórios à Wilhelmstraße, endereço do Ministério das Relaçóes Exteriores, a importância de se estimular o fluxo de estudantes entre a Alemanha e os países visitados. Em relatório sobre visita à América Latina em 1922, o pesquisador do Instituto de Doenças Tropicais de Hamburgo, Friedrich Fulleborn, advertiu sobre a importância de estimular o ensino do alemão entre os estudantes, de traduzir para o espanhol prospectos da Universidade de Hamburgo, principalmente na Faculdade de Medicina, e de criar um posto para aconselhamento de estudantes estrangeiros. Considerou importante que o afluxo de estudantes das Américas Central e do Sul deixasse de rumar tão maciçamente para Paris, passando a considerar a Alemanha como destino. Os resultados dessa iniciativa viriam na simpatia e identificação que esses indivíduos passariam a nutrir pelo país onde vivenciaram intenso período como estudantes. Náo deixou de notar que a maior parte deles provinha das elites econômicas e políticas, das quais resultariam benefícios para a Alemanha em termos de comércio e influência (WULF, 1994). No mesmo ano, o professor da Universidade de Berlim, Fedor Krause, visitou pela segunda vez a América do Sul. Na passagem pelo Rio de Janeiro, entregou carta do pesquisador do Instituto de Moléstias Infecciosas de Robert Koch, Claus Schilling, ao diretor do Instituto Oswaldo Cruz e do Departamento Nacional de Saúde Pública, Carlos Chagas. $\mathrm{Na}$ carta, Schilling estimulou Chagas a enviar estudantes brasileiros para a Alemanha, dispondo-se a recebê-los e encaminhá-los "com conselhos e recomendaçôes”. Também manifestou a importância de retomada das relaçôes científicas entre Brasil e Alemanha, comprometidas pela Guerra, mas que se encontravam em plenas condiçóes de serem restabelecidas. Em visita ao Brasil também em 1922, o professor da Universidade de Berlim e

5 Arquivo Politico do Ministério das Relações Exteriores (Politisches Archiv des Auswärtigen Amtes, daqui por diante, $P A A$, seguido do número da ata e do documento): $P A A A 33422$ Hamburgische Gesandtschaft an das Auswärtige Amt II.08.1925. 
diretor do Hospital Paul Gehardt, Fritz Munk procurou incentivar a ida de estudantes brasileiros para as instituiçoóes alemâs, como fez na passagem pela Faculdade de Medicina de São Paulo. ${ }^{6}$

$\mathrm{Na}$ Argentina, alvo de muitas iniciativas da política alemã, professores alemães que atuavam no país e pertencentes à União Científica Alemã (Deutsche Wissenschaftlichen Verein) estimularam as relaçóes com acadêmicos e intelectuais locais e o intercâmbio de professores e estudantes, com apoio da chancelaria alemã, de associaçôes ligadas às colônias teutas e de grupos que congregavam companhias de comércio (RINKE, 1996). $\mathrm{O}$ professor de neurologia da Universidade de Buenos Aires, Vicente Dimitri, esforçou-se para intensificar a presença de convidados alemães na universidade e a troca de estudantes.

Inspirados pelas iniciativas da diplomacia cultural francesa, que criou uma rede de institutos bilaterais em vários países latino-americanos, os alemães ou grupos simpáticos à Alemanha procuraram fazer o mesmo, de maneira a congregar os pontos de apoio das relaçóes culturais. Em 1922, fundou-se na Argentina a Institución Cultural Argentino-Germana. No mesmo ano surgiu no Brasil a Sociedade dos Amigos da Cultura Germânica e, quatro anos depois, a Institución Cultural Chileno-Germana. Por ocasião da fundação da Sociedade dos Amigos, o representante alemão no Rio de Janeiro comunicou a Berlim a intenção de que ela se tornasse um ponto de difusão do idioma alemão e de suporte do intercâmbio acadêmico: "Devemos por todos os meios tentar fazer com que os brasileiros busquem a Alemanha com a finalidade de realizarem seus estudos e assim obterem noçôes claras da alta capacidade e saber alemães". ${ }^{7}$ O legado alemão também propôs visitas recíprocas de professores, artistas e personalidades.

Em 1930, foi criado o Instituto Teuto-Brasileiro de Alta Cultura, cuja direção coube ao reitor da Universidade do Rio de Janeiro, nascendo

6 "Munk e Rocha Lima no Centro Acadêmico Oswaldo Cruz", Jornal do Commercio, 24.08.1922. Ao Ministério das Relações Exteriores Munk mencionou o "insucesso da política cultural externa" nos países latino-americanos, em virtude da dificuldade de obter "nesses paises uma aproximação espiritual com a Alemanha e um interesse e compreensão pela mentalidade alemã" (PAAA 60445 Deutsches Generalkonsulat São Paulo VI B 13943/22)

7 PAAA 60445 Deutsche Gesandtschaft Rio de Janeiro an das Auswärtige Amt 21.11.1922. 
organicamente integrado à representação alemã. Teve entre seu corpo de colaboradores intelectuais e acadêmicos que tinham alguma relação com a cultura germânica, apresentando como finalidade "[...] animar e manter o intercâmbio intelectual de professores alemães, austríacos e brasileiros, incumbidos de cursos especiais." (INSTITUTO TEUTO-BRASILEIRO DE ALTA CULTURA, 1930).

A instituição argentina contou com recursos dos governos argentino e alemão, com o Ministério das Relaçôes Exteriores participando de forma ativa no intercâmbio de professores e estudantes, o que não ocorreu com a congênere brasileira, que mediante a crise econômica não pôde levar à frente seu programa de intensificação das relaçôes com o Reich (RINKE, 1996, p. 440-441). O legado alemão em Buenos Aires tinha em alta conta a troca de estudantes: "[...] faz parte dos nossos próprios interesses políticos atrair tantos estudantes quanto possível para nossas escolas superiores e deste modo executar uma propaganda cultural". Os dividendos dessa estratégia, segundo ele, ficaram evidentes com a Grande Guerra, já que, "[...] com poucas exceçôes, os estrangeiros que estudaram conosco permaneceram nossos bons amigos". ${ }^{8}$

Nem todos os professores alemães ou estrangeiros foram vistos como instrumentos convenientes para os propósitos da política cultural. Mal-entendidos de diversas ordens surgiram nas negociaçóes ou nas viagens, algumas vezes por fatores de caráter político. $\mathrm{O}$ médico Fedor Krause entrou em colisão com a comunidade de alemães no Brasil e na Argentina e com os colegas locais em função dos altos honorários que cobrou para operação da filha de um personagem ilustre. ${ }^{9}$ A visita do economista marxista Alfons Goldschmidt à Universidade de Córdoba provocou mal-estar em virtude dos posicionamentos políticos do acadêmico. ${ }^{10}$

Particularmente problemático foi o caso de Albert Einstein, cujas idas ao exterior guardavam enorme potencial para a política cultural alemá.

\footnotetext{
8 РАAА 60445 Abschrift Buenos Aires VI 5479/22.

9 РААA 78999. Deutsche Gesandtschaft Buenos Aires an das Auswärtige Amt 30.09.1920. Ver também "São Paulo - Interior. O Incidente Krause - Uma carta do professor alemão", Jornal do Commercio, São Paulo, 31.08.1920.

10 РАAА 12192 Deutsche Gesandtschaft Buenos Aires an das Auswärtige Amt II.I I.1922.
} 
No entanto, Einstein mostrou-se reservado em relação às tentativas de colaboração com os diplomatas, ao mesmo tempo em que era um reconhecido pacifista, tendo sido dos poucos que se recusou a assinar o Manifesto dos 93. Por conta disso, era considerado um traidor da pátria por seus compatriotas. Ademais, sua teoria da relatividade sofria ataques por parte da comunidade de físicos alemães, entre os quais se destacou o ganhador do Prêmio Nobel, Philipp Lenard, que a repudiou como "ciência judia" (BEYERCHEN, 1977). Como mostra Rinke (1996), a nomeação de Einstein como membro de honra do Instituto Germano-Argentino provocou reação contrária por parte de representantes da colônia alemã. Foi a partir do apoio da comunidade judaica da Argentina que o físico finalmente visitou o país em 1925 em viagem que incluiu passagem pelo Brasil e Uruguai, nos quais deixou excelente impressão.

$\mathrm{O}$ intercâmbio acadêmico com a Alemanha impactou as reformas do ensino ocorridas em países latino-americanos nos anos 1920. Pedagogos alemães visitaram Equador, Colômbia, El Salvador, Bolívia e Chile em missóes orientadas por propósitos de política cultural oficialmente destinadas a aconselhar reformas de instituições de ensino (RINKE, 1996).

Um dos principais obstáculos para a política cultural alemá foi a ativa diplomacia cultural exercida pela França na América Latina, como em outras regiốes em que se buscava conquistar nichos de influência por meio das relaçóes científicas. Como vimos, os franceses estavam muito mais confiantes com a vitória na Grande Guerra e com as dificuldades que circundavam a ciência alemã. Os alemães acompanharam com atenção as investidas dos concorrentes, sem perder de vista o crescimento da expressão internacional dos norte-americanos, que ganhavam musculatura na América Latina. $\mathrm{Na}$ Argentina, o legado alemão comunicou ao Ministério das Relaçôes Exteriores em 1927 que a Espanha havia nomeado como novo representante um literato, ao invés de um diplomata profissional. Registrou ainda as crescentes açôes dos franceses, ingleses e norte-americanos no país, com a criação de institutos culturais bilaterais similares ao alemão. "A rivalidade entre as potências, que na Europa se expressa predominantemente no campo político e na Argentina ocorreu até agora no terreno econômico, estende-se gradualmente também para o domínio cultural", escreveu a Berlim."

II PAAA 6117I Deutsche Gesandtschaft Buenos Aires an das Auswärtige Amt 26.I2.1927. 
Em linha de continuidade com as estratégias adotadas antes, os franceses concentraram forças no intercâmbio acadêmico. O Groupement reativou suas atividades, principalmente a recepção de estudantes e pesquisadores latino-americanos nas universidades francesas, na divulgaçáo das possibilidades de estudo para os latino-americanos na França, no incentivo de pesquisas sobre América Latina, por meio da criação de cadeiras universidades e, ainda, pelo financiamento de escolas francesas e de viagens científicas pelo Ministério das Relaçóes Exteriores francês e publicação da Revue de l'Amerique Latine (PETITJEAN, 1996). A chancelaria francesa assumiu centralidade crescente na articulação do intercâmbio acadêmico. A criação do Service des Oeuvres Français à l'Étranger (SOFE) em 1920 foi expressão disso (SUPPO, 2000) Cerca de 90\% do seu orçamento foi destinado à Seção Universitária e de Escolas (SANTOMAURO, 2012).

Os principais pontos de apoio da diplomacia francesa na América Latina foram os institutos culturais bilaterais acima mencionados. A execução dessa política para a região contou com o protagonismo do já referido George Dumas, que entre 1920 e 1938 realizou 17 missóes aos países latino-americanos. O Instituto Franco-Brasileiro, sediado no Rio de Janeiro, promoveu entre 1920 e 1939 a vinda de 41 professores franceses para dar cursos, a maioria dos quais selecionados pelo próprio Dumas (PETITJEAN, 1996).

No caso da Alemanha, muitas das iniciativas de política cultural foram endereçadas conjuntamente à América Latina e aos países ibéricos pela questão do idioma. Livros traduzidos e professores alemães que dominavam o português e o espanhol muitas vezes circulavam pelas duas regiôes. Em Portugal, a política cultural envolveu a visita e contratação de pesquisadores, com destaque à área médica, na qual a Alemanha tinha particular prestígio por ter desenvolvido o modelo de ensino médico que conjugava a clínica, a pesquisa e o ensino universitário. Os alemães contaram, nesse sentido, com a colaboração de intelectuais no fomento da aproximação intelectual entre os dois países, como Gustavo Cordeiro Ramos, que ocupou o Ministério da Instrução Pública entre 1930 e 1933, o professor de Direito da Universidade de Coimbra, Luís Cabral de Moncada, e o diretor do Instituto Alemão ligado à mesma universidade, João Providêncio Sousa e Costa. Fundado em 1925, o Instituto Alemão teve apoio de instituiçóes 
alemãs como a União das Escolas Superiores Alemãs e o Instituto Ibero-Americano de Hamburgo. Ocupou-se do ensino da língua alemã e difusão da literatura germânica e da acolhida de acadêmicos (NINHOS, 2016). Conforme mostra Cláudia Ninhos (2016), com a criação da Junta de Educação Nacional pelo governo português em 1929, as relaçôes luso-germânicas passaram a envolver de forma mais sistemática o intercâmbio de estudantes, inclusive com contatos com agências alemãs de fomento à pesquisa, como a Sociedade de Auxílio à Ciência Alemã (Notgemeinschaft der deutschen Wissenschaft). Os alemães procuraram neutralizar a ativa diplomacia cultural posta em ação por França e Inglaterra no país ibérico.

Apesar do empenho da diplomacia alemã em coordenar as relaçóes científicas com o exterior em favor da política cultural, as iniciativas muitas vezes corriam por fora dos círculos oficiais, a partir dos canais informais mantidos pelos cientistas com seus pares estrangeiros. Muitas vezes eles que comunicavam espontaneamente suas viagens e propostas ao Departamento Cultural e representaçóes diplomáticas ou lavravam relatórios em que apresentavam sugestôes de açôes de política cultural. Tirante as idiossincrasias, certamente agiam motivados pela intenção de reconquistar o prestígio da ciência e cultura alemá, fruto do nacionalismo a partir do qual se autoinvestiam da missão de representantes legítimos da nação. Mas também procuravam os diplomatas com o fito de obterem vantagens, simbólicas, e também materiais, já que o Departamento Cultural auxiliava com recursos para as viagens e facilidades, como isenção de taxas, descontos nas passagens e acesso facilitado a círculos privilegiados. No caso dos estudantes, as propostas para aumentar o afluxo para as universidades alemâs passavam por facilidades como as sugeridas por Schädel, como isenção de taxas de matrícula, custeio de passagens, oferta de cursos de idioma, facilidades de acomodação e reconhecimento da formação no estrangeiro. Várias recomendações foram encaminhadas à Wilhelmstraße sugerindo a importância de favorecer o afluxo de estudantes em vista de seu significado para a política cultural.

A reforma monetária e consequente estabilização do marco ocasionou o recuo no número de estudantes estrangeiros na Alemanha, razão pela qual foi estabelecido, em 1925, um rebaixamento no valor da matrícula para eles. Paralelamente, França e Estados Unidos intensificaram 
o recrutamento para suas universidades, provocando inquietação entre os envolvidos com a política cultural no Reich. Como tentativa de estimular a imigração de estudantes, oficiais do Ministério das Relaçóes Exteriores e do Ministério da Educação da Prússia reuniram-se com representantes das instituiçóes acadêmicas com vistas a discutir a melhor estratégia. Decidiuse pela criação, em 1925, de uma fundação de caráter privado, destinada a conceder bolsas para estrangeiros interessados em estudar na Alemanha, com o claro propósito de estimular vínculos culturais por meio de estudantes que atuariam como "multiplicadores", ou seja, capazes de estimular a simpatia pela cultura alemã a partir de sua própria vivência nas instituiçóes de ensino superior do país (IMPEKOVEN, 2013). Denominada Fundação Alexander von Humboldt, ela não deveria mostrar-se como instrumento evidente de política cultural, mas como um órgão independente de concessão de bolsas, apesar de contar com recursos do Ministério das Relaçôes Exteriores. Como mostra Impekoven (2013), o próprio nome tinha por sugestão uma agência de longa tradição, desvinculada dos propósitos da diplomacia da República de Weimar. Em documento do Ministério das Relaçóes Exteriores de junho de 1925: "Por motivos evidentes, o nome [Fundação Alexander von Humboldt] é assim conferido apenas com o objetivo de que o Ministério das Relaçóes Exteriores não apareça como seu financiador no estrangeiro." (Ministério das Relaçóes Exteriores apud Impekoven, 2013, p. 20).

Apesar de procurar encobrir esse caráter político, ele tornou-se evidente na seleção dos estudantes que deveriam ser contemplados com a bolsa. De 1925 a 1930, houve entre 250 e 320 solicitaçóes a cada ano, das quais foram concedidos entre 50 e 60 auxílios. A maior parte das solicitaçóes, bem como as concessóes, foi da Europa oriental, principalmente dos Bálcâs, o que para Impekoven (2013) mostra o esforço, por meio da política cultural, de construção de um "império informal” na região que era um satélite tradicional da França e Alemanha. ${ }^{2}$ Dessa maneira, os estipêndios tinham clara conotação política no sentido dos eventuais dividendos gerados a partir de determinado candidato, em termos de sua origem geográfica e significado para os investimentos de política cultural.

12 Sobre a política cultural alemã na Grécia durante o nazismo, ver: Maria Zarifi (2010). 
Também em 1925 foi criado na Universidade de Heidelberg o Serviço de Intercâmbio Acadêmico, inicialmente voltado para o financiamento de bolsas para estudantes norte-americanos na Alemanha e vice-versa. A ideia surgiu do Instituto de Ciências Sociais da Universidade, mas que logo se transferiu para Berlim, estendendo-se para outras universidades. Breve houve um aumento no número de estudantes norte-americanos na Alemanha (LAITENBERGER, 1976). Em 1931, essa agência de Heidelberg deu origem ao Serviço Alemão de Intercâmbio Acadêmico (Deutscher Akademischer Austauschdienst) (DAAD), o qual incorporou a Fundação Humboldt, que manteve, entretanto, sua personalidade jurídica. A finalidade dessa fusão foi centralizar, sob a coordenação do Ministério das Relaçôes Exteriores, a política de atração, recepção, financiamento e encaminhamento de estudantes para as escolas superiores alemás. ${ }^{13}$

Se por um lado procurou-se equacionar o problema do financiamento dos estudantes, por outro persistiu o obstáculo do idioma. Em 1925, surgiu na Universidade de Munique a Academia Alemã (Deutsche Akademie), semente do que se tornaria, depois da Segunda Guerra, o Instituto Goethe, que minoraria a barreira do idioma, ainda que originalmente ela não fosse criada com esse objetivo. Como mostra Eckard Michels (2004), as origens da Academia remontam à movimentação de professores da Universidade dois anos antes, motivados pela luta contra a ocupação do vale do Ruhr pelas forças Aliadas. Segundo eles, a Alemanha devia seguir o exemplo da própria França, que derrotada na Guerra de 1870 conquistou simpatia por meio da propaganda cultural. A nova instituição dedicou-se a promover a cultura alemã no exterior e pesquisas sobre a herança cultural germânica. Seus objetivos originais eram centralizar tarefas orientadas pelos propósitos da política cultural: enviar professores alemães para o exterior, contribuir para a difusão de livros alemães e assegurar melhores condiçóes para os estudantes estrangeiros na Alemanha. Ao entrar em funcionamento, a Academia alterou suas finalidades para o apoio de minorias alemãs que viviam no estrangeiro, um ponto importante da política cultural diante da presença de uma série de povos de origem teuta em territórios dos antigos impérios Russo e Austro-Húngaro e de outros que outrora pertenceram à

13 Sobre o $D A A D$ e a politica cultural alemã, ver: Laitenberger (1976). 
Alemanha. Nos anos 1930, passou a concentrar suas atividades no exterior e com subvenção cada vez maior do Ministério das Relaçôes Exteriores (MICHELS, 2004).

Essa plêiade de instituiçóes a partir de meados dos anos 1920 refletiu também a abordagem do chanceler Gustav Stresemann, que perseguiu em sua política externa a reintegração da Alemanha no cenário internacional por meio da reaproximação com as demais potências ocidentais. Por causa disso, enfatizou as iniciativas de política cultural. Em 1925, a Alemanha assinou os Tratados de Locarno, que pretendiam pôr fim ao revanchismo alimentado principalmente pelos franceses, e sinalizavam para a superação efetiva das diferenças que haviam levado à Primeira Guerra. O chamado "espírito de Locarno" refletiu-se na arena científica, com o boicote dos cientistas aliados aos poucos cedendo lugar a atitudes conciliatórias (SCHROEDER-GUDEHUS, 1986). Tal como previsto pelos acordos de Locarno, a Alemanha entrou na Liga das $\mathrm{Na}$ ções em 1926. Se antes cientistas alemães já participaram de alguns comitês, como o diretor do Instituto de Doenças Tropicais de Hamburgo, Bernhard Nocht, no Comitê de Higiene, depois do ingresso oficial eles puderam se movimentar com maior liberdade no cenário internacional. As relaçóes com os países ibéricos e ibero-americanos se avultaram, tornando-se bastante intensas no final dos anos 1920. Apesar disso, o número de estudantes latino-americanos permaneceu baixo em comparação com os de outras regióes. Em 1925, dos 7.924 estudantes estrangeiros, 102 provinham da América Latina (RINKE, 1996).

A importância das relaçôes com a América Latina para a política cultural externa e negociaçóes envolvendo diplomatas, autoridades ligadas ao governo prussiano e intelectuais comprometidos em estreitar as conexóes do continente com a Alemanha levaram à criação, em 1930, do Instituto Ibero-Americano de Berlim (IAI) (RINKE, 1996; LIEHR et al., 2003). O novo Instituto tornou-se o principal ponto de coordenação de tais relações, entre as quais teve importância o aconselhamento e encaminhamento de estudantes e professores. A tal ponto que inclusive teve representação no DAAD. Muitas organizaçóes bilaterais de promoção do intercâmbio cultural do mundo ibero-americano com a Alemanha passaram a ser coordenadas pelo IAI. Em 1930, veio à luz a Sociedade Germano-Hispânica 
(Deutsch-Spanische Gesellschaft), principal órgão intermediário das relações culturais entre Alemanha e Espanha, as quais incluíram intercâmbio de acadêmicos e estudantes (JANUÉ I MIRET, 2008).

Em 1931, um ano depois da fundação do Instituto, a Alemanha apresentou o maior número de estudantes estrangeiros em todo o período que se estende da República de Weimar ao final da Segunda Guerra (URBAN, 2005). Com a subida de Hitler ao poder, a rede de instituiçóes envolvidas na política cultural e no intercâmbio de estudantes e professores entrou no processo de "coordenação" ideológica (Gleichschaltung), segundo o qual as agências do Reich deveriam seguir as diretrizes políticas do regime que incluíam a tese de supremacia racial, anticomunismo e o antissemitismo. Apesar do caráter altamente nacionalista e segregador do nacional-socialismo, permaneceu a finalidade de internacionalização, perseguida, entre outros meios, pelo intercâmbio de estudantes e professores (NINHOS, 2016).

\section{Migração acadêmica em tempos de fascismo: intercâmbio de estudantes e professores no nacional-socialismo}

A tomada do poder pelos nazistas em 1933 impactou diretamente na organização acadêmica e científica alemã. Com a Lei de Restauração do Funcionalismo Público, decretada em 7 de abril de 1933, parcela significativa dos professores de ensino superior e pesquisadores foram expulsos de suas funçóes. A medida repercutiu internacionalmente, acentuando as reservas contra o novo regime. O novo Ministério da Propaganda, que a partir dali competiria com a Wilhelmstraße e o Ministério da Ciência e Educação nas atribuições da política cultural externa, encarregou-se de esclarecer às escolas superiores os significados da ascensão nazista ao poder, minimizando seus impactos e apresentando-o como inofensivo à vida social e acadêmica. Pelo contrário, segundo o Ministério, o regime recém-empossado transformaria para melhor o sistema de ensino superior, o que não convergia com o quadro fornecido pela expulsão de professores e estudantes por razóes políticas e "raciais". Paralelamente, além dos tradicionais oponentes da Alemanha no terreno cultural, França e Estados Unidos, outros países como Itália, Espanha e Portugal levaram a frente políticas ativas de intercâmbio acadêmico, com particular destaque à Itália fascista, 
onde o número de estudantes estrangeiros em dez anos triplicou. Os alemães acompanharam esses avanços com preocupação. Representantes diplomáticos enviaram relatórios preocupados com o comprometimento do intercâmbio acadêmico. No mesmo mês de abril de 1933, o Ministro da Educação da Prússia, Bernhard Rust, assegurou que os estudantes estrangeiros continuariam sendo bem recebidos na Alemanha e com apoio oficial. O DAAD também se encarregou de remeter material de propaganda ao exterior (IMPEKOVEN, 2013).

Em termos gerais, o número de estudantes estrangeiros caiu, com maior redução entre os norte-americanos e os da Europa Oriental, os últimos pelo fato de incluírem alta fração de judeus. Em 1933, quando Hitler tornou-se chanceler, havia 6.587 estudantes estrangeiros na Alemanha; no semestre de inverno do mesmo ano, cerca de dois mil deles haviam deixado o país, metade dos quais por serem judeus (HAFINGER, 2016).

A princípio a política cultural externa mostrou linhas de continuidade com o que era feito na República de Weimar. A partir de 1936, com o Departamento de Cultura do Ministério das Relaçôes Exteriores passando a se denominar Departamento de Cultura Política, e depois de Hitler afirmar em discurso de 1937 a relevância de um império baseado não apenas na "espada e no escudo", mas também em uma "alta cultura”, é que ganhou impulso intervenções mais sistemáticas no terreno cultural por parte do regime nazista. Nesse mesmo ano foi criada uma nova seção naquele Departamento, voltada ao intercâmbio acadêmico (NINHOS, 2016). Dessa forma, a diplomacia tradicional procurou salvaguardar como sua atribuição a política cultural, crescentemente reivindicada pelo Ministério da Propaganda de Goebbels, pelo Ministério da Educação e pela Organização Estrangeira do Partido Nazista. Assim, a política cultural externa submeteu-se às mesmas disputas, contradiçóes e impasses que caracterizam o regime nazista como "policrático" (ZARIFI, 2010; JANUÉ I MIRET, 2016). Aos poucos, a distinção entre política e propaganda cultural, reivindicada pela diplomacia tradicional, foi perdendo nitidez, convergindo as iniciativas para o terreno da "pura propaganda" (NINHOS, 2016, p. 55). Nessa disputa, o DAAD e a Fundação Humboldt saíram da esfera de competência do Ministério das Relaçóes Exteriores, passando para o da Propaganda. A Academia Alemã, por sua vez, converteu-se no mais 
poderoso instrumento da propaganda cultural, com uma rede de mais de 250 filiais (MICHELS, 2004).

Como aponta Hafinger (2016), estudantes do sudeste europeu contaram com o apoio de organizaçóes econômicas que congregavam empresas e bancos alemães no financiamento de suas estadias na Alemanha. $\mathrm{O}$ autor argumenta que muito embora os nazistas considerassem as trocas acadêmicas com outros países europeus como um meio de persuadir suas elites da superioridade da cultura alemã e, dessa forma, assegurar a hegemonia cultural e acadêmica germânica, com consequente conexão política e econômica, elas não podem ser vistas como meras ferramentas de um imperialismo cultural. Para Hafinger, eles ambicionavam um "reordenamento" do continente segundo pressupostos racialistas. As bolsas para estudantes do Norte e Leste Europeu visavam, portanto, "fortalecer a coesão da 'raça germânica". Desse ponto de vista, seriam menos estratégias de "aproximação cultural" do que de distanciamento, uma vez que a cultura era expressão da raça, de maneira que os "parceiros" seriam selecionados de acordo com seu aporte "racial". Os nazistas teriam interesse em conhecer a cultura estrangeira e, ao mesmo tempo, em se manterem distantes dela. "Paradoxalmente, o intercâmbio acadêmico e cultural levaria a um tipo de apartheid cultural dentro da Europa, com a 'cultura germânica' sendo a dominante.”, escreve Hafinger (2016, p. 61).

Em estudo sobre as relaçôes culturais entre Portugal e Alemanha no nacional-socialismo, Cláudia Ninhos (2016) mostra como o intercâmbio acadêmico foi uma dimensão sobressaliente na aproximação entre os dois países. Segundo Ninhos (2016), a Junta de Educação Nacional e, a partir de 1936, o Instituto de Alta Cultura estabeleceram acordos de trocas de estudantes e professores com o DAAD. A complexa rede de instituiçóes envolvidas nas relaçóes culturais luso-germânicas deu suporte a esse intercâmbio, não sem conflitos e tensôes, promovendo o estudo do idioma e a divulgação da arte e das ciências nas duas formaçôes sociais. Concentrando-se nas elites intelectuais portuguesas, entre as quais se incluíam os estudantes e professores, a política cultural alemá mirou criar grupos simpáticos à "nova Alemanha", capazes de influenciar os rumos do Estado Novo de Salazar, sem deixar de considerar os benefícios econômicos dessa abertura. A estadia acadêmica nas reputadas instituiçóes germânicas, 
já estimulada na República de Weimar, teve por finalidade despertar esse respeito e admiração pela Alemanha de Hitler. Conforme Ninhos (2016, p. 381) “[...] levar os estrangeiros para a Alemanha e, aí treiná-los segundo os modelos pedagógicos e científicos alemães permitia conquistá-los e convencê-los da sua suposta superioridade científica e cultural". Evitando executar mera propaganda, as principais agências engajadas nesse movimento concentraram-se em uma política de efeitos de médio e longo prazo, a qual se estendeu praticamente até o fim da Segunda Guerra. Ninhos (2016) argumenta ainda que a circulação acadêmica entre Portugal e Alemanha contribuiu para a constituição de agendas de pesquisa e áreas de conhecimento, principalmente nas ciências naturais.

No caso da Espanha, as relaçóes culturais com a Alemanha tornaram-se mais intensas e revestidas de maior interesse político por parte dos nazistas a partir da Guerra Civil. O apoio às forças de Franco, que compartilhavam com os nazistas a repulsa ao comunismo, refletiu-se em maior aproximaçáo no terreno cultural. Para os alemães, a Espanha também despertava interesse como "ponte" para a América Latina, onde esperavam neutralizar as investidas dos norte-americanos. Os órgãos envolvidos nas relaçôes culturais hispano-germânicas, aos poucos, foram se subordinando à filial local do DAAD, que junto com a Fundação Humboldt, concedeu bolsas para espanhóis estudarem na Alemanha. Escolas para ensinar o alemão também foram criadas no país ibérico. Em 1939, a aproximação resultou em um Acordo de Colaboração Cultural que previa intensificação do intercâmbio acadêmico, mas ele não entrou em vigor pela oposição do Vaticano. Com a eclosão da Segunda Guerra, as relaçôes culturais se ampliaram. A Universidade de Madrid manteve um intercâmbio significativo com a Alemanha. Em 1941, fundou-se na capital espanhola uma filial do Instituto Científico Alemão (Deutsche Wissenschaftliche Institute), o qual passou a centralizar a política cultural nazista no país, trabalhando em estreita colaboração com as outras instituiçôes, como o DAAD e o Instituto Ibero-Americano. À medida que a guerra foi evoluindo, as relaçóes entre Espanha e Alemanha esfriaram, com a primeira optando por manter a neutralidade, apesar de tratativas no sentido de integrá-la ao Eixo (JANUÉ I MIRET, 2016).

Conforme mostra Cláudia Ninhos (2016), com a Segunda Guerra, a circulaçáo de professores e estudantes entre a Alemanha e o estrangeiro 
ficou dificultada. Apesar disso, houve um reforço da política cultural externa nos países militarmente ocupados e nos demais, inclusive com aumento de orçamento, maior protagonismo das instituiçóes oficiais em relação às privadas e incremento no número de bolsas. A Fundação Humboldt concedeu cerca de mil bolsas entre 1941 e 1944 (IMPEKOVEN, 2013). Muitos dos estudantes que afluíram para a Alemanha nesse período provieram de universidades austríacas e tchecas (HAFINGER, 2016). A execução dessa política cultural coube em grande medida à rede de Institutos Científicos Alemães (Deutsche Wissenschaftliche Institute). O primeiro foi fundado em abril de 1940, mas eles logo se expandiram para dezesseis capitais europeias (HAUSSMANN, 2001). O fomento do intercâmbio acadêmico da Alemanha com os respectivos países esteve entre as atribuições desses institutos. A importância da dimensão acadêmica nas suas tarefas pode ser auferida pelo fato de a direção dos institutos ser entregue a professores universitários que tinham relação com o país que os sediava, em termos de interaçóes e temas de pesquisa.

Em alguns casos, o intercâmbio acadêmico foi proposto como ponta de lança da política cultural em áreas em que a Alemanha pretendia expandir sua órbita de influência, como nos Bálcãs. Na Bulgária, um enviado da Wilhelmstraße indicou a criação de uma filial do DAAD como ponto de coordenação das atividades. Ele tinha em mira criar uma rede da agência por todos os Bálcãs, a qual atuaria como ligação para a atuação no Oriente (NINHOS, 2016). Programas de intercâmbio do DAAD incluíram durante a Guerra, além de Portugal, Espanha e países do Leste Europeu, os países escandinavos (HAFINGER, 2016).

\section{Algumas ações da política cultural nazista no Brasil}

As relaçôes culturais com a América Latina concentraram-se nas mãos do IAI e de seu diretor, o general Wilhelm Faupel, que havia sido adido militar no Peru e Argentina durante a República de Weimar e representante de Hitler na Espanha franquista. Ele assumiu a direção do IAI em 1934, dedicando-se a partir daí a centralizar na instituição toda a rede de agências privadas, semiprivadas e estatais engajadas nas relaçóes com a América Latina, incluindo a série de associaçóes econômicas bilaterais da Alemanha com os países "ibero-americanos", como os alemães preferiam 
denominá-los. Dessa forma deslegitimavam a ideia de "latinidade" que abastecia as propagandas francesa e italiana, assim como a de "pan-americanismo", que era o cerne da atuação norte-americana na região. No tocante ao intercâmbio acadêmico, o IAI trabalhou em cooperação com as demais instituiçóes do Reich, como o DAAD e a Fundação Humboldt, além do próprio Ministério das Relaçôes Exteriores e das organizaçôes de coordenação de pesquisa e ensino superior. O IAI intermediou solicitaçóes de bolsas de latino-americanos às respectivas agências, como o DAAD. Por exemplo, Faupel pediu cinco bolsas a colombianos interessados em estudar veterinária na Alemanha, as quais poderiam reverter na aquisição de cavalos de raça (BOSEMBERG, 2006). ${ }^{14}$

Como nas demais áreas de intercâmbio cultural da Alemanha, na América Latina houve prevalência das trocas nas áreas da medicina, ciências naturais e engenharia. Particularmente a medicina foi o campo mais ativo dentre eles no caso do subcontinente, em virtude da reputação internacional que a Alemanha gozava na área. Parcela significativa de latino-americanos haviam se formado ou se especializado em instituiçóes médicas alemãs. Durante a República de Weimar, médicos compuseram a maior parte dos alemães que visitaram os países latino-americanos para dar cursos e conferências. ${ }^{15}$ A política cultural da Wilhelmstraße foi atenta ao significado político e social de investir nos médicos, por serem em geral indivíduos das elites, vindo a ocupar posiçóes políticas importantes nos governos locais. Consciente disso, Faupel articulou, em 1935, junto com o renomado chefe de cirurgia do Hospital Charité, Ferdinand Sauerbruch, e o prefeito de Berlim, Julius Lippert, a Academia Médica Germano-Ibero-Americana (Deutsch-Ibero-Amerikanische Ärzte Akademie), com a finalidade de coordenar as estadias de médicos e estudantes de medicina interessados em visitar as instituiçóes do Reich. Em razão do significado do intercâmbio médico para a política cultural, a Academia nasceu com suporte do Ministério das Relaçôes Exteriores, da Propaganda e da Ciência e Educação da Prússia, além do apoio de instituiçóes privadas como a IG Farben (REGGIANI, 2005).

14 Mais sobre o Instituto Ibero-Americano durante o nacional-socialismo está em Liehr, Mailhold e Vollmer (2003).

15 Para saber mais, ver: Rinke (1996). 
Cerca de mil médicos latino-americanos visitaram a Alemanha sob os auspícios da Academia. Nos jogos olímpicos de 1936, a instituição organizou cursos de especialização ministrados em espanhol. A experiência bem-sucedida fez com que fosse repetida nos anos seguintes. Nas ediçôes posteriores, ofereceu "cursos itinerantes", nos quais uma comissão de estudantes e professores latino-americanos percorriam universidades e instituiçôes médicas de várias cidades alemãs. ${ }^{16} \mathrm{Na}$ capital do Terceiro Reich, o trajeto incluiu visitas ao IAI, às representações diplomáticas e a instituiçôes políticas. Brasil e Argentina foram os países que contribuíram com maior percentual de participantes nas ações da Academia. O alto número de brasileiros fez com que organizassem cursos específicos em português. Cerca de 200 médicos e estudantes de medicina frequentaram esses cursos, que tiveram suporte do DAAD. ${ }^{17}$

A Academia contou com um corpo consultivo de representantes locais nos países ibéricos e latino-americanos denominados "senadores", selecionados de acordo com a reputação, mas principalmente pelo nível de identificação cultural com a Alemanha, sendo excluídos os de ascendência judaica. Na Alemanha, os "senadores" abrangiam os médicos que dominavam o espanhol ou português e de projeção em sua especialidade. ${ }^{18}$ Apesar de não conceder bolsas, a Academia encaminhava os interessados em estabelecer contato com personalidades e instituiçóes alemãs procurando assegurar facilidades, como hospedagem, descontos nas passagens, etc. ${ }^{19}$ No caso do Brasil, o senador foi o patologista Walter Bungeler, professor da Escola Paulista de Medicina. ${ }^{20}$ Ele foi o principal responsável em articular a participação dos brasileiros nas iniciativas da Academia. ${ }^{21}$ Bungeler apresentou

16 GStA Rep. 218 A N. II Lehrgang der Deutsch-Iberoamerikanischen Ärzte Akademia vom 09-21.08.1937.

$17 P A A A 65670 D A A D$ an das Auswärtige Amt 22.1 1.1937. A relação dos médicos que visitaram a Alemanha entre 1937 e 1939 está em GStA Rep. 218 A N. 14 Brief an den J. F. Lehmanns Verlag am 20.09.1938. Ver também GStA Rep. 218 A N. 17 Médicos que visitaram a Alemanha no último trimestre.

18 Evitaram a todo custo empregar o francês (GStA Rep 218 N. I Abschrift eines Schreibens an das Dekanat der Medizinischen Fakultät Berlin am 20.07.1935).

19 A título de exemplo, GStA Rep 218 N. 6 Actividades del Academia Médica Germano-Ibero-Americana.

20 Além de Bungeler, os senadores da Academia Médica no Brasil foram Raul Leitão da Cunha, Antônio Austresgésilo, Maurity Santos, Antônio Abreu Fialho e João Marinho de Azevedo. Geheimes Staatsarchiv Preußisches Kulturbesitz - GstA Rep. 218 A N. 7 - Lista dos senadores da Deutsch-Ibero-Amerikanische Ärzte Akademie.

21 Ver, por exemplo, РAAA 65670 Deutsch-Ibero-Amerikanische Ärzte Akademie an das Auswärtige Amt II.II.1937. 
a Berlim uma série de propostas para aperfeiçoamento da política cultural no Brasil via medicina. Em relatório à Wilhelmstraße falou da importância de o governo alemáo subsidiar a importação de literatura especializada para o Brasil e sugeriu o intercâmbio de estudantes e professores assistentes entre os dois países como um meio eficiente de propaganda. ${ }^{22}$

O processo de contratação de Bungeler na Escola Paulista remete ao papel da política cultural nacional-socialista no ensino superior do Brasil: indicado pelo diretor da Escola, Octávio de Carvalho, que havia se especializado na Alemanha, Bungeler foi contratado em 1936 com uma série de vantagens, como manutenção do seu cargo em Danzig (então cidade livre alemã, futura Gdansk), pagamento de viagem de férias na Alemanha, complementação salarial, possibilidade de exercer mais de uma atividade em São Paulo etc. Negociações delongadas envolveram Carvalho, a Wilhelmstraße, agências do Partido Nazista e o Ministério da Ciência e Educação. Isso tudo porque queria se garantir que o posto de professor de patologia não caísse nas mãos de algum alemão de origem judaica, como havia ocorrido no caso dos três professores contratados para a Faculdade de Filosofia, Ciências e Letras da Universidade de São Paulo (USP) três anos antes - Ernst Bresslau, Felix Rawitscher e Heinrich Rheinboldt, responsáveis pelas cadeiras de zoologia, botânica e química, respectivamente. Nesse caso, a indicação se deu por influência do microbiologista e patologista brasileiro, Henrique da Rocha Lima, que havia trabalhado no Instituto de Doenças Marítimas e Tropicais de Hamburgo entre 1909 e 1927, quando retornou ao Brasil. Rocha Lima foi o principal articular do intercâmbio médico-científico entre Brasil e Alemanha na primeira metade do século XX (SILVA, 2011). Ele visitou o país por seis meses em 1937-1938, com grande suporte da Academia Médica e do Ministério das Relaçôes Exteriores alemão, por ser considerado um "leal amigo da Alemanha" ("ein aufrichtiger Freund von Deutschland”). ${ }^{23}$ Apesar disso, a indicação de professores de origem judaica para a USP e outras instituiçôes de São Paulo desagradou alguns, como o higienista Martin Ficker, que liderava na capital paulista uma Estação de Microbiologia da Sociedade Kaiser Wilhelm.

22 РАAА 65577 Bericht der Tätigkeiten Professors Walter Bungeler.

23 РААA 67670 Deutsches Generalkonsulat São Paulo an das Auswärtige Amt 06.07.I 937. 
Tanto ele quanto Bungeler consideravam que professores judeus não eram representantes autênticos da Alemanha. Aparentemente os oficiais da Wilhelmstraße compartilharam da mesma opinião, já que se recusaram atender o pedido dos professores da USP de obter as mesmas vantagens que os contratados da França e Itália, de complementação salarial e férias pagas. Para Berlim, eles poderiam inclusive atuar de forma contrária aos interesses alemães. ${ }^{24}$

Além de Rocha Lima, outros médicos de renome visitaram a Alemanha no período do nacional-socialismo, como o professor de dermatologia da Faculdade de Medicina de São Paulo, Adolpho Lindenberg; o chefe da clínica da mesma escola, Octacílio Gualberto de Oliveira ${ }^{25}$; o professor de terapêutica clínica da Escola Paulista de Medicina, Felício Cintra do Pra$\mathrm{do}^{26}$; o professor de neurologia da Faculdade de Medicina do Rio de Janeiro, Antônio Austresgésilo, o diretor do Hospital Psiquiátrico do Juqueri, Antônio Pacheco e Silva, ${ }^{27}$ Carlos de Moraes Barros, que em 1936 foi em visita oficial para conhecer a organização de saúde e assistência do Terceiro Reich, ${ }^{28}$ bem como Coryntho Silva, que foi com a mesma finalidade, em viagem oficial por encargo do Ministério do Trabalho. O médico militar Carlos Eugênio Guimarães liderou missão médica dedicada a conhecer o serviço de saúde do exército alemão, com apoio da Siemens e da Seifert. ${ }^{29}$ A relevância política fez com que alguns fossem cercados de atenção

24 Este caso está analisado em Silva (2013). As negociações entre os professores da USP e o Ministério das Relações Exteriores estão muito bem documentadas em PAAA 61171. As negociações para a contratação de Walter Bungeler para a Escola Paulista de Medicina estão igualmente bem registradas em PAAA 63965.

25 Brazilian Legation 17 December 1935, to German Foreign Office [Letter]; Der Staatskommissar der Hauptstadt Berlin 3 January 1936, an das Auswärtige Amt [Letter]. PAAA. Akte 65670. Berlin: German Foreign Office.

26 РАAA 65670 Deutsch-Ibero-Amerikanische Ärzte Akademie an das Auswärtige Amt 10.03.1938.

27 No caso de Pacheco e Silva, os alemães levaram em conta o fato de que ele era um dos cotados para ocupar o cargo de ministro da cultura caso o então governador de São Paulo. Armando Salles de Oliveira, ganhasse as eleições de 1937 e assumisse a presidência, o que não ocorreu devido ao golpe do Estado Novo (PAAA 65670 Deutsches Generalkonsulat an das Auswärtiges Amt 15.05.1937. Sua carta de agradecimento pela acolhida especial na Alemanha foi encaminhada a Goebbels (PAAA 67670 Auf dem Erlass vom 05.08.1937). Também $P A A A 65670$ An den Reichsminister fur Volksaufklärung and Propaganda 08.07.1937.

28 PAAA 65670 Brazilian Embassy 9 October 1936 to German Foreign Office [Letter]; President of Reich Health Office 14 October 1936, to Oster (German Foreign Office) [Letter]. Berlin: German Foreign Office

29 Gradenwitz, W. 10 March 1934 to Muhlens, P. [Letter]; Muhlens, P. 14 March 1934 an die Gesundheits- und Fursorgebehörde Gesundheitswesen [Letter]; Der Reichswehrminister an das Auswärtige Amt 19 March 19 1934. РAAA. Akte 63965. Berlin: German Foreign Office. 
especial, como o filho de Getúlio Vargas, Luthero Vargas, e Heitor Annes Dias, que era médico do então ditador. $\mathrm{O}$ mesmo ocorreu com o reitor da Universidade do Brasil, o professor de histologia da Faculdade de Medicina Raul Leitão da Cunha. ${ }^{30}$ José de Magalhães Carvalho e Rudolpho Kleinosheg permaneceram na Alemanha em 1936 para completarem seus estudos, com bolsa da Fundação Humboldt. ${ }^{3 !}$ Os interesses desses professores não ficaram restritos à esfera acadêmica. $\mathrm{O}$ professor de oftalmologia da Escola Paulista de Medicina, Moacyr Álvaro, visitou organizaçóes nazistas como a Deutsche Arbeitsfront (DAF), a Kraft durch Freude (KdF) e um campo de Serviço de Trabalho (Reichsarbeitsdienst) ${ }^{32}$, onde os jovens alemães eram obrigados a temporariamente prestar serviço como parte da doutrinaçáo no novo regime.

Entre acadêmicos e pesquisadores de outras áreas, que não a medicina, que estiveram na Alemanha na mesma época está o diretor da Escola Superior de Agricultura de Viçosa João Carlos Bello Lisboa ${ }^{33}$; o fitopatologista do Instituto Biológico de São Paulo, Agesilau Bitancourt ${ }^{34}$; o engenheiro militar e professor da Escola Técnica do Exército e da Escola Politécnica da Universidade do Rio de Janeiro, Francisco Xavier Kulnig ${ }^{35}$; os professores da mesma escola, Victor Ribeiro Leusinger ${ }^{36}$ e Maurício Joppert da Silva ${ }^{37}$ e o também engenheiro do Instituto Paulista de Tecnologia, Odair Grillo. ${ }^{38}$

No caso do intercâmbio de estudantes e professores da Alemanha com a América Latina, o Ministério das Relaçóes Exteriores teve interferência crescente dos órgãos do Partido Nazista, principalmente da Organização Estrangeira, que punha em ação uma política cultural paralela, mais alinhada com os pressupostos ideológicos nacional-socialistas e seus ideais de

30 РААА 65670 Central Hotel an das Auswärtige Amt 14.09.1935.

31 РАAA 65670 Raul Leitão da Cunha an die Deutsch-Ibero-Amerikanische Ärzte Akademie 15.01.1936. DAAD an die Alexander von Humboldt Stiftung 15.01.1936.

32 РААA 65670 Rundschreiben Zu Nr. Kult W Nr. 18364/37.

33 РААА 65670 Deutsche Kalisyndicats an den Reichministerium fur Ernährung und Landswirtschaft 12.10.1933; IG Farben an das Auswärtige Amt 10.10.1933 und an den Preusischen Ministerium fur Wirtschaft

34 РААА 65670 Deutsche Konsulat São Paulo an das Auswärtige Amt 08.04.1934: Hamburg Staatsamt an das Auswärtige Amt 19.06.1934; President der Kaiser Wilhelm Gesellschaft an Agesilau Bitancourt 15.06.1934

35 РААA 65670 Botschaft der Vereigniten Staaten von Brasilien an das Auswärtige Amt 05.07.1938

36 РАAА 65670 Der Reichsverkehrminister an den DAAD 22.02.1937.

37 РААА 65670 Der Reichsminister der Luftfahrt an das Auswärtige Amt 24.09.1936.

38 РААA 65670 Reichs- und Preußiche Wirtschaftsminister an das Auswärtige Amt 02.02.1938 
propaganda. Choques frequentes originaram-se dessa sobreposição, como em dezembro de 1937, quando a embaixada alemã no Rio demonstrou irritação a Berlim por ter recebido solicitação do Instituto Ibero-Americano a pedido do chefe do Partido Nazista do Brasil, Hans Henning von Cossel. ${ }^{39}$

No sentido contrário, visitaram o Brasil entre 1933 e 1942 os médicos Ludolph Brauer, ${ }^{40}$ Walter Benthim, Heinrich Herfarth, Karl Wedell, Franz Keysser, ${ }^{41}$ Heinrich Huebschmann, ${ }^{42}$ o professor de cirurgia de Heidelberg, Martin Kirschner; o especialista em cardiologia, pessoa de confiança de Heinrich Himmler e médico e pesquisador das SS, Karl Fahremkamp, ${ }^{43}$ e os especialistas em radiologia e radioterapia, Hans Holfelder e Gottfried Boehm. ${ }^{44}$ Holfelder era decano da Faculdade de Medicina da Universidade de Frankfurt e como Fahrenkamp fez carreira nas SS, escalando a hierarquia da corporação até chegar ao nível de General de Brigada (Oberfuhrer) em 1944. Nas brigadas de Himmler coordenou equipe responsável por fazer diagnósticos de tuberculose por radiologia, não só entre os pertencentes das SS, mas também entre descendentes de alemães que viviam nas regióes ocupadas pelos nazistas. ${ }^{45}$ Grande repercussão entre os brasileiros teve a visita dos especialistas em tuberculose: o professor de Cirurgia do Tórax e diretor do Hospital Municipal de Tuberculose de Berlim Waldhaus, Hellmuth Ulrici, e o diretor da terceira policlínica médica da Universidade de Berlim, Walter Unverricht. ${ }^{46} \mathrm{O}$ amigo de Hitler e diretor da Clínica Universitária de Frankfurt, Franz Volhard, foi recebido calorosamente no Rio de Janeiro e em São Paulo em 1938.47

39 РАAA 65670 Deutsche Botschaft Rio de Janeiro 09.12.1937.

40 PAAA 66586 Bericht der Reise Ludolph Brauer an das Auswärtige Amt 31.10.1934.

41 РАAA 65577 Auswärtiges Amt an den sudamerikanischen Deutschen Botschaften 16.03.1940.

42 РАAA. 65576 Bericht des Deutschen General Konsulats Porto Alegre an das Auswärtige Amt 19.1 I.1938.

43 PAAA 61134 Deutsche Gesandstchaft Rio de Janeiro an das Auswärtige Amt 29.1 I.1933.

44 Sobre a viagem de Goffried Boehm PAAA 67680 Faculdade de Medicina de Porto Alegre a Gottfried Boehm 26.10.1933.

45 Holfeder também participou, no campo de Warthegau, do planejamento do assassinato de 35 mil poloneses infectados com tuberculose. Morreu em batalha durante a Segunda Guerra (KLEE, 2003).

46 PAAA 65576 Reichs- und Preußischer Minister fur Wissenschaft, Erziehung und Kultur an das Auswärtige Amt 03.1 10. 1938. Notícia da palestra de Unverricht no Instituto Teuto-Brasileiro de Alta Cultura em dois de fevereiro de 1938, traduzida pelo encarregado da companhia Schering no Brasil, encontra-se em: Diário de Notícias, Rio de Janeiro 30.01.1938, p. 7.

47 PAAA 65576 Deutsches Generalkonsulat an das Auswärtige Amt 09.1938. 
A investida dos norte-americanos na América Latina, inclusive no terreno da diplomacia cultural, tornou cada vez mais difícil a execução da política alemã na região, principalmente depois do início da Segunda Guerra. A título de exemplo, cabe mencionar ofício que a legação alemã em Bogotá enviou a Berlim antes mesmo de iniciar o conflito, em que o representante diplomático afirmou que se desconsiderasse o envio de cientistas alemães em vista da forte influência norte-americana no país. ${ }^{48}$

A intensa pressão política de Washington fez com que países como o Brasil entrassem no conflito em 1942 contra os alemães. A partir daí as relaçóes culturais com a Alemanha praticamente estagnaram. Terminado o conflito, as instituiçôes alemãs envolvidas na promoção do intercâmbio acadêmico ressurgiram, tendo, no entanto, de lidar com a incômoda herança do envolvimento direto com a política nazista. Parte significativa dos vestígios desse envolvimento havia sido destruída, como os arquivos do DAAD e do IAI.

\section{Considerações finais}

A trajetória histórica aqui percorrida mostra a gênese da rede de instituiçôes até hoje atuantes na promoção da língua e cultura alemã e na atração de estudantes internacionais para suas instituiçóes de ensino superior. Alguns autores avaliam a efetividade dessas políticas pelo impacto nas decisóes e alinhamentos políticos dos países-alvo. Nesse sentido, teriam sido inócuas ao não assegurarem alianças, como no caso de Portugal, da Espanha ou mesmo do Brasil, que participou da Segunda Guerra ao lado dos Estados Unidos. Concentrar-se nesse parâmetro empobrece a análise uma vez que não considera a densidade das redes transnacionais pelas quais fluíram pessoas, projetos, ideias e conhecimento. Em certos casos, os laços culturais com a Alemanha complexificaram o cenário. Para mais uma vez mencionarmos o caso do Brasil, o proverbial “jogo duplo" de Vargas só foi possível pela efetiva proximidade que havia entre seu governo e segmentos sociais importantes com o Terceiro Reich, a qual causava inquietação em Washington.

48 РААА 65577 Deutsche Gesandtschaft Bogotá an das Auswärtige Amt 23.08.1939. 
Muito embora esse percurso histórico da política cultural externa alemã não seja retilíneo, já que houve rupturas de grande significado, como a Segunda Guerra, a divisão do país em dois blocos e a reunificação, há continuidades entre instituiçóes, estratégias e propósitos entre o período aqui analisado e a configuração atual. Hoje a Alemanha é um dos países com alto grau de internacionalização do ensino superior e boa reputação internacional devido a uma política cultural no estrangeiro em que o incentivo à migraçáo de estudantes e pesquisadores é central.

Nota-se nessa trajetória a tentativa de instrumentalização do intercâmbio acadêmico por parte da diplomacia oficial, mas muitas das interaçóes ocorreram em decorrência de contatos espontâneos entre acadêmicos e cientistas. Muitas vezes partiram destes a iniciativa de chamar atenção das chancelarias para a importância das trocas acadêmicas como estratégias de política cultural no estrangeiro, formulando abordagens para executá-la de forma eficaz.

Como aponta Cláudia Ninhos (2016), o estudo de personagens como professores e estudantes permite ampliar o ângulo de análise das relaçóes internacionais, trazendo à cena atores que estavam fora do quadro diplomático e lógicas e motivaçóes náo referidas à dimensão política ou econômica e ao Estado nacional. Não se trata de pensar apenas como as relaçóes culturais se integram às relações internacionais, mas como elas obedecem a dinâmicas próprias, implicando diversidade de atores, abordagens e interesses; trocas de conhecimentos, experiências, percepçóes e projetos.

Muito embora articulemos aqui iniciativas de mobilidade acadêmica transnacional com a internacionalização, é preciso levar em conta que ela não foi necessariamente a motivação dos atores históricos do início do século XX. Havia o ideal de uma ciência "internacional”, práticas similares às que hoje se executam em políticas de internacionalização, mas a "comunidade internacional" encontrava-se segmentada e profundamente comprometida com propósitos nacionalistas. Potências culturais, como Alemanha, França, Inglaterra e Itália procuravam, por açóes de fomento das trocas acadêmicas, atrair as regióes de ação para suas órbitas de influência cultural, política e econômica. $\mathrm{O}$ objetivo de cada uma delas foi concentrar as relaçóes dos países-alvo em seu favor, para tanto digladiando-se com seus 
oponentes na esfera cultural. Do ponto de vista dos países que procuravam excelência e desenvolvimento em centros de maior tradição acadêmica, as motivaçóes aproximavam-se das que ainda hoje impelem os mesmos países a formularem políticas nacionais de migração de professores e estudantes. Dessa forma, a ideia de internacionalização precisa ser historicizada, assim como o rótulo "internacional", que teve significados específicos de acordo com o período e com os atores que o mobilizaram. Nas primeiras décadas do século XX, ele passou por transformaçóes, mas foi indissociável das naçóes e nacionalismos exacerbados, os quais "capturaram" seus sentidos em favor de seus próprios objetivos e interesses. Os atores do intercâmbio - estudantes e professores - atuaram em conjunção com órgãos oficiais e semioficiais, mas como agentes movidos por objetivos particulares, que em grande medida gravitaram em torno de ambiçóes profissionais, não estando ausentes motivaçóes de ordem política. $\mathrm{O}$ fator político, nesse sentido, pôde atuar como incentivo, mas também como obstáculo. Os "alvos" das ações de política cultural não foram inertes: apropriaram-se das ofertas de possibilidades de estudar no exterior e alavancar suas reputaçóes pela relação com instituiçóes e parceiros estrangeiros, muitas vezes fazendo uso estratégico das iniciativas dos alemães, franceses, norte-americanos etc, sem que necessariamente apresentassem laços de identificação com os respectivos países e suas culturas. Esse traço fica bastante evidente no caso do Brasil, em que, apesar de forte identificação das elites com a cultura francesa e, mais tarde, com a norte-americana, houve um considerável intercâmbio acadêmico com a Alemanha. Esse intercâmbio impactou na constituição de instituiçôes e áreas do conhecimento. Antes da constituição de agências nacionais como CNPq e CAPES, as relaçôes estabelecidas pelos acadêmicos brasileiros com o exterior foram, em muitos casos, propiciadas pelas possibilidades abertas pelas iniciativas de propaganda cultural e por redes intelectuais mantidas informalmente.

Em suma, uma mirada histórica sobre a internacionalização possibilita concebê-la como processo complexo, que articula atores de diversas escalas e motivaçóes de naturezas distintas, que nunca se restringem aos elementos intrínsecos da prática científica e acadêmica. Como essas atividades, é um processo profundamente imbricado com as esferas política, econômica, social e cultural. 


\section{Referências}

ANTELO, A. Internationalization of research. Journal of International Education and Leadership, (S,1.), v. 2, n. 1, p. 1-6, 2012.

ARAÚJO, E. R.; SILVA, S. Temos de Fazer um Cavalo de Tróia: elementos para compreender a internacionalização da investigação e do ensino superior. Revista Brasileira de Educaçáo, [online], v. 20, n. 60, p. 77-98, jan./mar. 2015.

BEYERCHEN, A. D. Scientists under Hitler: Politics and the Physics Community in the Third Reich. New Haven: Yale University Press, 1977.

BOSEMBERG, L. E. Alemania y Colombia, 1933-1939. Iberoamericana, Alemania y Colombia, v. 21 , p. $25-44,2006$.

BOURDIEU, P. Os usos sociais da ciência: por uma sociologia clínica do campo científico. São Paulo: Unesp, 2004.

BURKE, P. Uma História Social do Conhecimento: de Gutenberg a Diderot. Rio de Janeiro: Zahar, 2003.

CHARLE, C. Introduction to Part II: Intellectual Transfer and Cultural Resistance. In: CHARLE, Christophe et al. (Org.). Transnational Intellectual Networks: forms of academic knowledge and the search for cultural identities. Frankfurt: Campus, 2004.

The Intellectual Networks of Two Leading Universities: Paris and Berlin 1890-1930. In:

CHARLE, Christophe et al. Transnational Intellectual Networks: forms of academic knowledge and the search for cultural identities. Frankfurt: Campus, 2004b.

CHARLE, Christophe et al. (Org.). Transnational Intellectual Networks: forms of academic knowledge and the search for cultural identities. Frankfurt: Campus, 2004.

CRAWFORD, E. Nationalism and Internationalism in Science, 1880-1939: four studies of the Nobel Population. Cambridge: Cambridge University Press, 1992.

FORMAN, P. Scientific internationalism and the Weimar Physicists: the ideology and its manipulation in Germany after World War I. Isis, Chicago, v. 64, n.2, p. 151-180, 1973.

FUCHS, E. The International Catalogue of Scientific Literature as a Mode of Intellectual Transfer: Promises and Pitfalls of International Scientific Co-operation before 1914. In: CHARLE, Christophe; SCHRIEWER, Jurgen; WAGNER, Peter. (Org.). Transnational Intellectual Networks: forms of academic knowledge and the search for cultural identities. Frankfurt: Campus, 2004. 
DAVID-FOX, M. Leftists versus Nationalists in Soviet-Weimar Cultural Diplomacy: Showcases, Fronts and Bumerangs. In: SOLOMON, S. G. (Ed.) Doing Medicine Together: Germany and Russia between the Wars. Toronto/ Buffalo/ London: University of Toronto Press, 2006. p. 103-156.

DREWEK, P . The Inertia of Early German-American Comparisons: American Schooling in the German Educational Discourse. In: CHARLE, Christophe; SCHRIEWER, Jurgen; WAGNER, Peter. (Org.). Transnational Intellectual Networks: forms of academic knowledge and the search for cultural identities. Frankfurt: Campus, 2004.

DUWELL, K. Deutschlands Auswärtige Kulturpolitik, 1918-1932. Grundlinien und Dokumente. Colônia/Viena: Böhlau, 1976.

GOEBEL, M. Decentering the German Spirit: The Weimar Republic's Cultural Relations with Latin America. Journal of Contemporary History, Los Angeles, v. 44, n. 2, p. 221-245, 2009.

GROSS, Stephen. Export Empire: German Soft Power in Southeastern Europe, 1890-1945. Cambridge: Cambridge University Press, 2016.

HAFINGER, J. Student and Scholar Mobility between Nazi Germany and Southern/ Southeastern Europe. In: CLARA, F; NINHOS, C. (Ed.). Nazi Germany and Southern Europe, 1933-1945. New York: Palgrave Macmillan, 2016, p. 52-67.

HARWOOD, J. Styles of Scientific Thought. The German Genetics Community 1900-1933, Chicago 1993.

HAUSSMANN, F. R. Auch im Krieg schweigen die Musen nicht: die Deutschen Wissenschaftlichen Institute im Zweiten Weltkrieg. Göttingen: Vandenhoeck \& Ruprecht, 2001

IMPEKOVEN, H. Die Alexander von Humboldt-Stiftung und das Ausländerstudium in Deutschland 1925-1945. Von der 'geräuschlosen Propaganda' zur Ausbildung der 'geistigen Wehr' des Neuen Europa. Bonn: Vandenhoeck \& Ruprecht, 2013.

JANUE I MIRET, M. Imperialismus durch auswärtige Kulturpolitik: die Deutsch-Spanische Gesellschaft als 'zwischenstaatlicher Verband' undter dem Nationalsozialismus. German Studies Review, v. 31, n. 1, p. 109-32, 2008

Relaciones culturales en el Nueva Orden: la Alemania nazi y la España de Franco. Hispania, v. 75, n. 251, p. 805-32, sept./dec. 2015. The Role of Culture in German-Spanish Relations during National Socialism. In: CLARA, F.; NINHOS, C. (Ed.). Nazi Germany and Southern Europe, 1933-1945. New York: PalgraveMacmillan, 2016. 
KARADY, V. Student Mobility and Western Universities: Patterns of Unequal Exchange in the European Academic Market. In: Charle, Christophe; Schriewer, Jurgen; Wagner, Peter. (Org.). Transnational Intellectual Networks: forms of academic knowledge and the search for cultural identities. Frankfurt: Campus, 2004.

KIRCHHOFF, J. Die Notgemeinschaft der Deutschen Wissenschaft/ Deutsche Forschungsgemeinschaft, 1920-1934: Schwerpunktlegungenn der Forschungspolitik der Weimarer Republik. Ludwig-Maximilians-Universität Munchen, Munique, 2003.

KLEE, Ernst (Ed.). Das Personal Lexikon zum Dritten Reich. Frankfurt a.M: S. Fischer, 2003. KLOOSTERHUIS, J. Friedliche Imperialisten: Deutsche Auslandsvereine und auswärtige Kulturpolitik, 1906-1918. Frankfurt a.M.: Peter Lang, 1994.

KNIGHT, Jane. Internationalization Remodeled: Definition, Approaches, and Rationale. Journal of Studies in International Education, (S.1.), v. 8, n. 1, p. 5-31, 2004.

LAITENBERGER, V. Akademischer Austausch und auswärtige Kulturpolitik. Der Deutsche Akademische Austauschdienst (DAAD), 1923-1945. GoÈ ttingen, 1976.

LIEHR, R.; MAILHOLD, G.; VOLLMER G. (Ed.). Ein Institut und sein General: Wilhelm Faupel und das Ibero-Amerikanische Institut in der Zeit des Nationalsozialismus. Frankfurt a.M.: Vervuert, 2003. 67-129.

MICHELS, E. Deutsch als Weltsprache? Franz Thierfelder, the Deutsche Akademie in Munich and the Promotion of the German Language Abroad, 1923-1945 German History, v. 22, n. 2, p. 206-228, 2004.

NINHOS, C. Para que marte náo afugente as Musas. A Política cultural alemã em Portugal e o intercâmbio académico (1933-1945). 2016. 99 f. Tese (Doutorado em História Contemporânea) Universidade Nova de Lisboa, 2016.

PETITJEAN, P. Ciências, Impérios, Relaçôes Científicas Franco-brasileiras. In: HAMBÚRGUER, A.I. et al. (Org.). A Ciência nas Relaçóes Brasil-França, 1850-1950. São Paulo: Edusp, 1996.

PRESAS I PUIG, A. On a Lecture Trip to Spain: the Scientific Relations Between Germany and Spain During the Entente Boycott, 1919-1926. Annals of Science, v. 65, n. 4, 529-546, 2008.

REGGIANI, A. H. Medicina y Kulturpolitik en la era del nacionalsocialismo: la Academia Médica Germano-Ibero-Americana. In: CARRERAS, S. (Org). Der Nationalsozialismus und Lateinamerika. Ibero On Line, v. 3, n. 1, p. 57-74. 2005.

RINKE, S. H. Der letze freie Kontinent: Deutsche Lateinamerikapolitik im Zeichen transnationaler Beziehungen, 1918-1933. Stuttgart: Heinz. 1996. 
SA, M. R.; VIANA, L. M. La science médicale entre la France et le Brésil: stratégies d'échange scientifique dans la période de l'entre-deux guerres. Cahiers des Amériques Latines, Paris, v. 65, p. 65-88, 2010.

SANCHEZ, J. M. L. Política Cultural Exterior Alemana en España durante la República de Weimar. Cuadernos de Historia Contemporanea, v. 25, p. 235-253, 2003.

SANTOMAURO, F. De Brésil to Brazil. A política cultural como instrumento de poder: os casos de França e Estados Unidos no Brasil na primeira metade do século XX. In: SUPPO, H. R.; LESSA, M. (Org.). A Quarta Dimensáo das Relaçóes Internacionais: a dimensão cultural. Rio de Janeiro: Contra Capa, 2012.

SANTOS, B. S. Os processos de Globalização. In Santos, B. S. (Org.) Globalização: fatalidade ou utopia? Porto: Afrontamento, 2002.

SCHRIEWER, P. Multiple Internationalities: the emergence of a World-Leven Ideology and the Persistence of Idiosyncratic World-Views. In: CHARLE, Christophe et al. (Org.). Transnational Intellectual Networks: forms of academic knowledge and the search for cultural identities. Frankfurt: Campus, 2004.

SCHROEDER-GUDEHUS, B. Les Scientifiques et la paix: la communauté scientifique internationale pendant les anées vingt. Montreal: Presses de l’Université de Montréal. 1978.

SCHROEDER-GUDEHUS, B. Pas de Locarno pour la Science, Relations Internationales, v. 46, p. 173-, 1986.

SILVA, A. F. C. A trajetória científica de Henrique da Rocha Lima e as relaçóes BrasilAlemanha, 1901-1956. 2011. 839 f. Tese de Doutorado (História das Ciências e da Saúde) Programa de Pós-Graduação em História das Ciências e da Saúde. Casa de Oswaldo Cruz/Fiocruz, Rio de Janeiro, 2011.

A Diplomacia das Cátedras: a política cultural externa alemã e o ensino superior paulista - os casos da USP e da Escola Paulista de Medicina, 1933-1942. História Sáo Paulo, v. 32, n. 1, p. 401-431, jan./jun. 2013.

SOLOMON, S. G. (Ed.). Doing Medicine Together: Germany and Russia between the Wars. Toronto/ Buffalo/ London: University of Toronto Press, 2006.

STICHWEH, R. From the Peregrinatio Academica to Contemporary International Student Flows: National Culture and Functional Differentiation as Emergent Cases. In: CHARLE, Christophe et al. (Org.)Transnational Intellectual Networks: forms of academic knowledge and the search for cultural identities. Frankfurt: Campus, 2004. 
SUPPO, H. A política cultural da França no Brasil entre 1920 e 1940: o direito e o avesso das missões universitárias. Revista de História, São Paulo, v. 142/143, p. 309-345, 2000.

SZÖLLÖZI-JANZE, M. Science and Social Space Transformations in the Institutions of Wissenschaft from the Wilhelmine Empire to the Weimar Republic. Minerva, v. 43, p. 339-360, 2005.

UNGER-STERnBERG, W.; UNGER-STERnBERG, J. Der Aufruf An die Kulturwelt!: das Manifest der 93 und die Anfänge der Kriegspropaganda im Ersten Weltkrieg. Peter Lang, 2014.

URBAN, J. Die lateinamerikanischen Studierenden an der Universität Hamburg 1919- 1970. Hamburg: Institut fur Iberoamerika-Kunde (Beiträge zur Lateinamerikaforschung, Bd. 5, 2005.

VOM BROCKE, B. Der deutsch-amerikanische Professorenaustausch: Preußische Wissenchaftspolitik, international Wissenschaftsbeziehungen und die Anfänge einer deutschen auswärtigen Kulturpolitik vor dem Ersten Weltkrieg. Zeitschrift fur Kulturaustausch, v. 31, p. $128-182,1981$.

WAGNER, P. Introduction to National Traditions and the Emergence of Transnational Forms of Knowledge. In: CHARLE, Christophe et al. (Orgs)Transnational Intellectual Networks: forms of academic knowledge and the search for cultural identities. Frankfurt: Campus, 2004.

WERNER, M. Philological Networks: a History of Disciplines and Academic Reform in Nineteenth-Century France. In: CHARLE, Christophe et al. (Orgs) Transnational Intellectual Networks: forms of academic knowledge and the search for cultural identities. Frankfurt: Campus, 2004 .

WULF, S. Das Hamburger Tropeninstitut 1919 bis 1945: auswärtige Kulturpolitik und Kolonialrevisionismus nach Versailles. Berlin; Hamburg: Reimer, 1994.

ZARIFI, M. Using Natural Sciences for Cultural Expansion: The National Socialist Agenda for the Balkans. The Historical Review/ La Revue Historique, v. 4, 199-233, 2007. 


\section{Historical Dimensions of Internationalization: the role of the german cultural diplomacy in the transnational academic mobility (1919-1945)}

\section{Abstract}

Internationalization is considered a fundamental process to improve the quality of higher education and scientific research. It is considered also as a result of contemporary globalization and its demands. One of the main aspects of the internationalization, the transnational mobility of students and researchers, is pursued and emphasized by the different policies and actors which promote it. This article analyzes internationalization as a historical dynamic that in the first decades of the 20th century was associated with the cultural diplomacy policies of the European countries and the United States. In this sense, it intends to show how it was articulated with the intense nationalism of the period and with the effort to change power correlations through the conquest of niches of cultural sympathy. The analysis focuses on the cultural diplomacy of Germany during the Weimar Republic and the Nazi regime, the country that was the protagonist of the two world wars. In Germany, the encouragement of the exchange of researchers and scholars assumed specific meanings, related to the international isolation after the Treaty of Versailles and with the ambition to obtain cultural and political hegemony. The strategies to achieve these goals varied according to the political context. The article shows details some initiatives directed to the Latin American countries, mainly to Brazil.

Keywords: Internationalization. Academic mobility. Cultural diplomacy. German foreign cultural policy. Weimar Republic. Nazi regime.

Recebido em: 17.08.2017

Aprovado em: 26.02.2018 